\title{
Sobre a Definição de Res Publica em Cícero (Rep. 1.39)
}

Márlio Aguiar

Despite the fact being one of the most sophisticated works of Marco Túlio Cicero, the De Re Publica and the concept of res publica (Rep. 1.39) still remain forgotten topics for beyond the sterile repetition of its words. Among the commonplaces are the overly individualizing, moralizing, or even updating and anachronistic readings of Cicero's political and jusnaturalist thought. The objective of this article is to offer an interpretation of Scipio's definition highlighting the institutional (and historically located) aspect of this concept. It will proceed by an analysis of the main elements that make up the definition (iuris consensus, utilitatis communio, sociatus-societas) and from the assumption that they form a conceptual complex that needs to be read in its wholeness.

Moribus antiquis res stat romana uirisque

Ênio (Cicero, Rep. 5.1)

Introdução

Estando às vésperas do bicentenário da redescoberta do manuscrito do tratado $D e$ Re Publica de Marco Túlio Cícero parece que ainda sabemos muito pouco a seu respeito.

É verdade que, em alguns casos, tal situação se deu de forma deliberada. Os adeptos dos métodos da Quellenforschung no século XIX, eivados pela ideia romântica do autor genial e original, tinham pouco a dizer a respeito de Cícero além de apontar, aqui e acolá, sua dívida intelectual (quando generosos) ou sua inferioridade (quando mais sinceros) para com os gregos. Escrevendo em 1839 pouco antes de lançar sua tese de doutoramento o jovem Karl Marx declarou que Cícero sabia menos de filosofia do que conhecia a respeito do presidente dos Estados Unidos. Para o liberal e expoente da Escola Histórica Alemã, Theodor Mommsen, a despeito da fama o tratado de Cícero parecia tão unphilosopische quanto unhistorische. $\mathrm{O}$ historiador Moses Finley, concordando com a afirmativa de Mommsen, reduziu as obras De Re Publica e o De Legibus de Cícero a meras peças retóricas, a um grande nonsense de função 
ideológica. Ronald Syme assim se expressou em uma azeda nota de rodapé a respeito do tratado De Re Publica: "a book about which too much has been written".

Se o século XIX e o começo do século XX foram períodos pouco ciceronianos, a tendência recente de diversas áreas parece ser a de olhar para os escritos do Arpinate com mais diligência ou até mesmo a intenção explícita de revitalizar sua leitura. Parece ser, pelo menos, o caminho dos Classical Studies (especialmente das pesquisas voltadas à Retórica e aos ambientes oratórios), da Ciência Política e da História das Ideias (um reavivar explicado, em parte, pelos escritos dos neorrepublicanos) alcançando a História do Direito Romano Público. ${ }^{2}$

O autor registra seus agradecimentos ao Prof. Sidney Calheiros de Lima (USP) e ao Prof. Tiago Losso (UFSC), bem como à leitura criteriosa do manuscrito pelos colegas Roger Manenti Laureano e Artur Fabro.

${ }^{1}$ A Quellenforschung (a pesquisa ou investigação, die Forschung, voltada às fontes, die Quellen) se coadunou num método profissional debruçado sobre as fontes da antiguidade com visas a traçar com precisão a confiabilidade e a validade desses testemunhos; seus resultados constituem até hoje um substrato importante para a filologia, filosofia e historiografia. O jovem Marx, em seu estudo sobre o epicurismo, assim escreveu: "Cicero might well laugh at it, he knew as little about philosophy as about the president of the United States of North America" Marx, Karl. "Notebooks on Epicurean Philosophy" [1839] in: Marx, Karl; Engels, Friedrich. Marx \& Engels Collected Works: Vol. 1, Karl Marx, 1835-43. (Lawrence \& Wishart/Eletric Book, 2010), p. 472. Para Mommsen, "Die Schrift vom Staat führt in einem wunderlichen, geschichtlich-philosophischen Zwittergebilde den Grundgedanken durch, daß die bestehende Verfassung Roms wesentlich die von den Philosophen gesuchte ideale Staatsordnung sei; eine freilich eben so unphilosophische wie unhistorische, übrigens auch nicht einmal dem Verfasser eigentümliche Idee, die aber begreiflicherweise populär ward und blieb", cf. Mommsen, Theodor. Römische Geschichte: Bd. von Sullas Tode bis zur Schlaft von Thapsus (Berlin: Weidmannsche Buchhandlung, 1856, vol. 3-3), p. 575. Para Finley, "there is only rhetoric, in which I include the Stoic notions of 'natural law' and 'natural reason' (...) Whatever genuinely philosophical meaning those terms may have had for the Stoics themselves, Cicero turned them into mere rhetoric, terms of 'approval for whatever idea (one) wanted to recommend at any particular time', in his case the Roman constitution of the good old days", Finley, Moses I. Politics in the Ancient World (Cambridge: Cambridge University Press, 1983), p. 128 e nt. 17. Veja-se também em Syme, Ronald. The Roman Revolution (Oxford: Clarendon University Press, 1939), p. 144, nt. 1, cuja leitura encontra ecos mesmo em reputados autores contemporâneos: é assim que T. P. Wiseman, aderindo a Syme, acredita que as análises de Cícero nos anos cinquenta eram "not all dispassionate. On the contrary it was the tendentious self-justification of a controversial politician at the crisis of his career", vide Wiseman, Timothy Peter. "Roman History and Ideological Vacuum" in: Remembering the Roman People: essays on Late-Republican Politics and Literature (Oxford: Oxford University Press, 2009), p. 7, 15-16. O Syme foi menos contido em seu capítulo sobre Cícero, a quem considerava "a fanatical and dangerous champion" da República oligárquica, alguém que "did not exhibit the measyre of loyalty and constancy, of Roman virtus and aristocratic magnitudo animi that would have justified the exorbitant claims of his personal ambition" (SYME, 1939, p. 146-147). Útil lembrar do aviso do próprio Syme (curiosamente, um conselho que, ofertado pelo historiador, não foi seguido na mesma página) a respeito da presunção de lançar-se "julgamentos sobre os mortos" ou simplesmente de verter como um esquadro axiológico nossos padrões de conduta e valor sobre o passado.

2 Apontem-se alguns exemplos que não contém necessariamente afinidades íntimas entre si, mas representam exemplos recentes de tais áreas de pesquisa. Quanto à primeira seara (mormente interdisciplinar entre os Classical Studies e a história da teoria política) podemos mencionar autores como Dean Hammer (Roman Political Thought from Cicero to Augustine, 2014), Joy Connolly (The Life os Roman Republicanism, 2015 e The State of Speech, 2013), Daniel Kapust (Republicanism, 
E, no entanto, em alguns de seus mais entusiastas intérpretes contemporâneos - que, inegavelmente, guardam o mérito de chamar à baila uma teoria política quase que expurgada do curriculum filosófico ocidental - muito do que haveria de valor no pensamento de Cícero parece vir implicitamente de sua "protomodernidade", de sua antecipação de aspectos modernos, nem sempre do que Cícero poderia ter significado para a Roma da República tardia. Às avessas, muitas análises - especialmente do tratado De Re Publica - procedem como se fizessem uma ressalva envergonhada à Quellenforschung e, tacitamente, trazem consigo as mesmas concepções a respeito do Arpinate que dos Oitocentos; faz-se desaparecer Cícero como homem de seu tempo, capaz de fazer diagnósticos ou teorizações próprias de sua sociedade. Se Cícero era pouco original em comparação com os gregos antigos, para vários dos grandes intelectuais do século XIX e começo do XX, noutras vezes, aparece como "original" porque pretensamente se pareceria com pensadores modernos. Cícero ganha pouco com isso, assim como nossa própria concepção do Arpinate, de sua obra e de seu milieu intelectual.

Situados dentro desse contexto de revitalização do pensamento de Cícero, nossa atenção se voltará à sua filosofia política e jurídica - a separação moderna entre as duas disciplinas não existia para ele - e, particularmente, para a extremamente debatida definição de res publica contida em Rep. 1.[25.]39 ${ }^{3}$ - res publica, res populi -, pronunciada por Cipião, mantida viva

Rhetoric, and Roman Political Thought, 2014) e Jan H. Blits (The Heart of Rome: Ancient Rome's Political Culture, 2014), ou o já mais antigo trabalho de Neal Wood (Cicero's Social and Political Thought 1988). Pensamos aqui na profusão teórica de Philipp Pettit (a partir especialmente de Republicanism: a theory of freedom and government, 1999). Dentro da área jurídica, Cícero também tem recebido atenção destacada de autores como Bruce W. Frier (The Rise of the Roman Jurists, 1985), Giovanni Lobrano (Res publica res populi, 1996), Clifford Ando (Roman Social Imaginaries, 2015), Jill Harries (Cicero and the Jurists, 2006), e na coletânea Cicero's Law: rethinking Roman Law of the Late Republic editada por Paul J. du Plessis. Um interesse dedicado pela filosofia romana, e também em Cícero, encontra-se marcado também nos dois volumes da coletânea Philosophia Togata: Essays on Philosophy and Roman Society (1989 e 1999), editada por J. Barnes e M. Griffin; e em Cicero the Philosopher editada por J. G. F. Powell. Um interesse em particular pela filosofia política move coletâneas como Cicero's Republic (2001) editada por J. G. F. Powell e J. A. North; e também Cicero and Modern Law (2009), editada por Richard O. Brooks.

${ }^{3}$ A literatura especializada europeia por vezes apresenta esta forma de citação, seguindo a edição de Angelo Mai, anotando Rep. 1.25.39. Por comodidade, neste artigo representaremos as citações apenas pela numeração do parágrafo (daí Rep. 1.39 ou Rep. 1, 39), mais usual. Este é o modo de citação da edição de Konrat Ziegler, ainda que ele apresente a paragrafação da edição Mai e, como este, a paginação do palimpsesto original Vat.lat.5757 (vide infra nt. 19). Quanto à edição Ziegler consultamos a primeira edição de 1915 (não obstante algumas revisões de estabelecimento até a sétima edição de 1969, o modo de citação e a ordem de fragmentos não se altera), seguido na tradução anglófona de Zetzel (1999) e na tradução lusitana de Francisco de Oliveira (2008). Consultamos ainda quanto ao estabelecimento latino de Rep. 1.39 a mais recente edição estabelecida por Powell (2006, Oxford). 
pela pena de Santo Agostinho e Isidoro de Sevilha ${ }^{4}$, e constantemente revisitada desde a circulação do texto original no primeiro quartel do século XIX. Como tentaremos aclarar a seguir, as interpretações correntes a respeito do conceito ciceroniano de res publica costumam oscilar ora em uma leitura excessivamente individualizante ou moralizante (as mais numerosas), ora em uma leitura institucionalista ingênua (geralmente, alimentada por um afã bastante anacrônico de tornar Cícero um prévio adepto liberal, constitucionalista ou contratualista), ou depositar a fé em velhas concepções a respeito do estoicismo ciceroniano. E, no entanto, é o aspecto institucional de sua definição o mais frequentemente esquecido nas análises a respeito da passagem.

Nosso intento será o de demonstrar que Cícero, na realidade, possui uma conexão sofisticada dos aspectos institucionais e morais a respeito tanto da res publica quanto dos cives que devem regê-la, e isso se dá pelo peso gravitacional dos termos iuris consensus, utilitatis communio e sociatus contidos na mesma definição, um esforço conceitual que buscava contemplar a história da República romana, descrever o funcionamento de suas instituições (mores, leges e iura) e fornecer critérios de análise. Propomos uma leitura que revitaliza o aspecto institucional da definição de res publica (Rep. 5.1, 5.5); não para "constitucionalizar" o De Re Publica, mas para tentar empreender uma leitura mais integral de seu conceito.

Por consequência, é preciso frisá-lo, este artigo também não tratará de algumas coisas. Não nos preocupa a questão a respeito da originalidade ou do "ecletismo" da definição de res publica de Cícero: por esta razão, embora comparações de seu pensamento com Políbio, Platão, Antíoco, Aristóteles e a Stoa sejam relevantes, tampouco procuramos definir em qual escola se encaixa o tratado de Cícero. Também não se trata de uma busca pelo ídolo das origens do republicanismo ou de criar uma mitologia doutrinária com um berço de ouro na última flor do Lácio. Sempre que algo em Cícero parecer "novo" ou "inédito" na literatura de seu tempo, esse fato em si será menos importante do que investigar em que consiste seu pensamento e como o Arpinate o operava dentro do contexto intelectual e político da República tardia. Por fim, estando cientes que nenhuma pesquisa é plenamente desinteressada - um Droysen ou um Weber já há muito assentaram a importância dos anseios e questões lançados pelo pesquisador, radicado em seu tempo e espaço -, este artigo também não tem o condão de "recuperar" em Cícero algo que falte ao nosso século. A principal lição que pode nos dar o passado não é um

\footnotetext{
${ }^{4}$ Agost. De Civ. Dei 19.21; e também em Isid. Etym. 9.4.5. Para uma análise da recepção medieval vide Kempshall, M. S. "De Re Publica 1.39 in Medieval and Renaissance Political Thought" in Powell, Jonathan G. F.; North, J. A. Cicero's Republic: Bulletin of the Institute of Classical Studies, Supplement n. 76, 2001, p. 101-105.
} 
catálogo de sugestões, mas a contemplação da alteridade. Não procuraremos em Cícero, por mais instigante que seja sua leitura filosófica, as soluções que neorrepublicanos, liberais e constitucionalistas buscam para o hoje. Na medida em que isto for possível, este artigo tem simplesmente o condão de compreender como Cícero construiu seu conceito no tratado De Re Publica, tratando de justificar textual e contextualmente suas opções. Isso nos leva a reabilitar os aspectos institucionais que derivam da definição de res publica, res populi.

Dividimos o artigo em duas partes principais. Na primeira buscamos contextualizar o tratado De Re Publica e das demais obras produzidas após o retorno de Cícero do seu exílio no período da década de cinquenta antes de Cristo. Resultado de um período de otium cum dignitate coincidente com a ascensão do primeiro triunvirato, tentamos chamar atenção para as questões daquela década que deram vazão à escrita de Cícero (1.1); e traçamos um breve itinerário do desenvolvimento do texto, da organização de seus seis livros e algo a respeito do estado fragmentário com que recebemos o livro (1.2). Na segunda parte nos dedicamos à definição de res publica. Após uma descrição de como Cícero apresenta seu próprio diálogo filosófico por meio de Cipião Emiliano e Lélio entre Rep. 1.1-38 (2.1), passamos à análise do texto de Rep. 1.39 (2.2), decompondo a discussão em duas subseções a partir dos elementos propostos por Cícero: a res publica é coisa do populus, e este se qualifica como uma associação humana muito particular (sociatus) marcada pelo iuris consensus e pela utilitatis communio.

\section{$O$ De Re Publica como tratado institucional e de filosofia política}

\section{O contexto de Cícero nos anos cinquenta}

A carreira pública de Cícero - alimentada por sua atuação como orador - desponta em finais dos anos sessenta tendo por auge seu consulado em 63 a.C. e a conjuração de Catilina, passando então pelo conturbado conflito entre os ordines e a formação do primeiro triunvirato durante o ano do consulado de César (59 a.C.). Não havia lugar para Cícero - ao menos, para o ativo pater patriae - entre os triúnviros a despeito de suas relações com Pompeu e César. Por alguns meses entre 58 e 57 a.C. Cícero teve negados e seus direitos como parte da civitas e se viu forçado ao exílio de Roma por sua atuação no consulado durante a conjuração de Catilina pelas manobras políticas de seu inimigo Públio Clódio Pulcro, que ascendera ao tribunato da plebe. O apoio da maioria dos tribunos daquele ano - entre eles, o partidário de Pompeu, Tito Ânio Milo, a quem Cícero defenderia em Pro Milo - foi fulcral para que o Senado enfim votasse pelo retorno de Cícero, que acompanhado da família foi recepcionado por sua filha Túlia e pela multidão. Seu retorno não significou, no entanto, que sua influência sobre as questões políticas 
tivesse sido restaurada ao status quo ante: os triúnviros se asseguraram disto em abril de 56 a.C. quando Cícero foi cordialmente intimado a dar seu apoio à renovação do primeiro triunvirato na Conferência de Luca. ${ }^{5}$

Durante toda a segunda metade daquela década, até se retirar à Cilícia como governador, Cícero se manteve distante da atuação política que tivera no passado, dando vazão à sua energia, por um lado, com suas orationes, e por outro, com a escrita filosófica, os primeiros passos definitivos de Cícero como autor de filosofia desde o juvenil tratado De inuentione. Durante 55-51 a.C. Cícero ainda fazia aparições memoráveis no Senado e nas cortes - nestas últimas, em causa própria ou de outros ${ }^{6}-$, mas que estava sob amarras e limites que não experimentara antes de seu consulado e de seu exílio. As obras filosóficas que foram fruto de sua situação política delicada: De Oratore (escrito por volta do ano 55 a.C.), De Re Publica (c. 54-51 a.C.) e o inacabado De Legibus (c. 52-51 a.C.), preocupadas, respectivamente, com o orador, com a teoria política e a vida cívica, e com a proposta de um conjunto de normas consistentes com a lei natural para guiar as instituições romanas. ${ }^{7}$ Todas as três obras têm em mente os correspondentes platônicos Fedro, Górgias, República e Leis, ainda que Cícero frequentemente nos lembre que sua tarefa não era nem a de emulação nem a de mera tradução (fosse literal, fosse meramente de transplante cultural) dos gregos. ${ }^{8}$ Não nos estranha assim que, como destacou Zetzel, a vida pessoal de Cícero influenciasse sua visão pessimista a respeito da concreta res publica de Roma nas obras que se seguiriam ${ }^{9}$. O contexto político dos anos

${ }^{5}$ Cic. Att. 4.1, uma carta de setembro de 57 a.C., contém a narrativa do próprio Cícero a respeito do seu retorno Cic. Fam. 1.9, datada de outubro 55 a.C., faz um sumário da relação de Cícero com os triúnviros após a Conferência, especialmente nos constantes avisos de Pompeu para apoio político.

${ }^{6} \mathrm{O}$ que não significa que Cícero não tenha, com sua atuação como patronus, atuado pública e politicamente. São particularmente relevantes neste sentido o autointeressado De Domo Sua (57 a.C.) frente ao Colégio dos Pontífices; o discurso como patrono, Pro Sestio (56 a.C.), familiar aos estudos de língua latina; e o ataque ao ex-cônsul Pisão em In Pisonem (55 a.C.). Nestas ocasiões são recorrentes os temas da dignitas individual (colacionada, no caso de Cícero, à sua submissão ao exílio), da maiestas do populus, da relação entre o bem-estar da res publica e o controle da violência (vis) e salvaguarda das instituições, costumes e direito (ius).

${ }^{7} \mathrm{O}$ próprio Cícero considerava suas obras dos anos cinquenta resultado de um período cum dignitate otium (pro Sest. 98). Lintott agrupa neste período como relevantes não apenas os três tratados mencionados, mas também como textos significativos uma carta ao historiador Luceio (Fam. 5.12), solicitando uma biografia de sua vida política entre o período do consulado e o retorno do exílio; o discurso pro Plancio; a carta Lêntulo Espínter (Fam. 1.9), documento importante sobre o período de tensão entre César e Pompeu, e as orações pro Gabinio. pro Rabirio Postumo e pro Milo, que se explicam no contexto da ligação política de Cícero com Pompeu.

${ }^{8}$ Cic. Acad. post. 1.3-12; de fin. 1.7-10 e 3.3-6; de nat. deor. 1.6-10.

${ }^{9}$ Zetzel, James E. G. "Political Philosophy" in Steel, Catherine (editor). The Cambridge Companion to Cicero (Cambridge: Cambridge University Press, 2013), p. 181-184. 
cinquenta faziam com que a questão da res publica tivesse contornos de urgência: reflete tanto o pensamento político e filosófico de Cícero (em sentido teórico lato sensu) quanto responde às necessidades políticas específicas e prementes no funcionamento da res publica.

É este o contexto geral das primeiras incursões de Cícero na escrita dos diálogos filosóficos sobre teoria política e instituições romanas. Muitos testimonia conhecidos a respeito do tratado De Re Publica refletem esse contexto na sua confecção, sobretudo um conjunto de cartas endereçadas ao seu irmão e ao amigo Ático no ano de 54 a.C. ${ }^{10}$, quando Cícero se devota à escrita deste tratado. ${ }^{11}$ Perceber as três obras como um conjunto de reflexões (e historicamente localizado, ademais) é fulcral, mesmo quando o intérprete se voltar mais pormenorizadamente para apenas um desses tratados, como faremos a seguir com o De Re Publica.

É igualmente importante não exagerar nem na leitura "individualizante" e "moralizante" nem na leitura "institucional" ou na leitura "jusracionalista", uma vez que, em Cícero, esses diferentes aspectos se encontram alinhavados ora de modo sofisticado, ora de modo truncado, mas jamais de modo monolítico. Em De Oratore - e, década seguinte, em Brutus - o autor dedica grande atenção à figura individual e à formação daqueles que devem guiar a política, tema similar ao dos livros quase inteiramente perdidos quatro e cinco do De Re Publica. Doutro lado, o inacabado De Legibus e os dois primeiros do tratado sobre a res publica tratam de temas institucionais e de teoria política, além da conformidade e legitimidade dessas instituições perante o direito natural (que aparece no fragmentado livro três do De Re Publica, pontua o De Legibus e outras obras posteriores como De Officiis).

As separações didáticas ou temáticas (como aquelas entre os dias de um diálogo) estão na sua pena, mas não apartam os terrenos da discussão teórica ${ }^{12}$ : o Arpinate estava tão preocupado com as questões institucionais que diziam respeito ao melhor tipo de res publicae como identificar, em uma res publica, potenciais perigos - quanto com as questões ligadas aos indivíduos que deveriam zelar por ela e geri-la, a nível de formação política, intelectual e

${ }^{10}$ Em Cic. $Q f r .2 .15 .4$ e Att. 4.15.8; e $Q f r .2 .13$, Att. 4.14.1 encontramos informações gerais a respeito de 54 a.C. e da vida de Cícero. As cartas que expressam as ideias de Cícero a respeito do De Re Publica em sua composição são particularmente $Q$. Fr. 2.12.1, Att. 4.16.2 e especialmente a carta $Q$. Fr. 3.5.1.

${ }^{11}$ Em geral, pode-se alocar o tema dessas cartas como dizendo respeito à relação entre o cidadão e o homem público com a estrutura das instituições da res publica; ou ainda, a relação entre a virtude a nível individual e a nível de sociedade. Nestas cartas Cícero está narrando como Catão, com bastante astúcia e virtude, encontrara um meio de prevenir fraude nas eleições daquele ano; e leva ao conhecimento de ambos que começou a escrever um trabalho a respeito da res publica.

${ }^{12}$ Também parecem assim pensar Powell, cf. Powell, Jonathan G. F. "Were Cicero's Laws the Laws of Cicero's Republic?" in Powell, Jonathan G. F.; North, J. A. Cicero's Republic: Bulletin of the Institute of Classical Studies, Supplement n. 76, 2001, p. 17-19. 
moral. ${ }^{13}$ Cícero transita (é verdade, muitas vezes de modo confuso, dificuldade que não nos socorre o caráter fragmentário dos textos De Re Publica e De Legibus) por acepções bastante particulares e contingentes - é quando tem em vista, acima de tudo, a Roma de seu tempo, as suas instituições, as suas normas, a sua formação histórica - e por acepções de teor universalista, sobretudo na sua posição jusnaturalista. Firme-se desde logo, no entanto, que seja para descrevê-las de modo realista, seja para críticas com fulcro numa ordem pré-estabelecida pela justiça, Cícero está convidando seus leitores à análise das instituições concretas de Roma.

Gênese, estrutura e transmissão do tratado De Re Publica

Uma vez que esse artigo irá se deter na questão da definição de res publica, algumas palavras gerais a respeito da estrutura da obra são necessárias previamente.

Cícero não deve ser lido em tiras: é um erro tanto apartar esses tratados uns dos outros, como também analisar como determinadas porções de uma obra influem no mesmo tratado. Já asseveramos que os três tratados da década de cinquenta possuem uma mesma teia de temas, motivados pelas mesmas preocupações. Ainda, os tratados De Re Publica e De Legibus foram escritos num arco temporal próximo e, se seguirmos a contundente hipótese de Schmidt, foram até mesmo planejados inicialmente como uma mesma obra. ${ }^{14}$ Em carta ao irmão Quinto $(Q . F$.

${ }^{13}$ Por uma leitura excessivamente individualizante inclinam-se Zetzel, Wood e Atkins; pela leitura mais moralizante (que pode se combinar com a anterior em diferentes graus) parecem se alinhar Schofield e Powell. Nosso ponto não é que Cícero dê destaque ao indivíduo. O indivíduo que move as instituições é importante e, em toda a obra de Cícero - não apenas filosófica, mas em suas oratones e epistulae - o peso das ações individuais é relevante. Efetivamente, o "indivíduo" ciceroniano tem peso na história e no curso das coisas: a marca da individualidade nos autoelogios de Cícero, ou nas figuras históricas de um Catão ou Cipião Emiliano (especialmente no Somnium Scipionis) são prova disto. Todavia, Cícero não é um autor da filosofia política moderna, muito menos um autor liberal (como insistentemente parecem lê-lo alguns de seus intérpretes atuais); para ele, o indivíduo se insere num contexto e, especialmente, numa dada ordem das coisas (que é tanto natural, no sentido da filosofia estoica ou platônica, fixando um kosmos que antecede o indivíduo; quanto humana, poiética, artificial, como aquela presente na distinção dos ordines) que é pré-existente às ideias humanas. Assim como não é liberal, Cícero não é um "proto-constitucionalista" e admite - que filósofo antigo não o fazia, com a exceção evidente dos sofistas ou dos cínicos? - a intervenção da mais alta Lex naturalis no ordenamento positivo. Outrossim, o jusnaturalismo de Cícero não é estático: é um padrão de legitimidade segundo o qual as instituições humanas são postas à prova. Os filósofos e os moralistas podem discutir essas questões e instruir seus concidadãos: no entanto, cabe ao populus, por meio das suas instituições, alterar, extinguir ou criar essas normas que, espera-se, espelharão a iustitia. Sem dúvida que, para Cícero, a res publica de homens virtuosos; igualmente, uma boa res publica é feita de instituições e normas que derivam da atividade desses boni viri e, na sua ausência, retardam os males que são inescapáveis aos homens, aos interesses e às lutas facciosas. Na filosofia política de Cícero os homens e as instituições agem juntos: aquele que conduz o leme do barco é importante, mas o barco também o é.

${ }^{14}$ As principais passagens a respeito da confecção do tratado, aponta Schmidt, jamais se referem explicitamente a um tratado que teria o título De Re Publica. Em Q.F.2.12.1 Cícero faz uma referência 
3.5.1), Cícero revela que planejava nove livros que se situariam nos nove dias de discussão de um novendiale sacrum, um feriado latino de expiação que se deu por conta de um prodigium em 129 a.C. (a saber, a aparição do "segundo sol” referenciado em Rep. 1.15, que se converteria simplesmente nas férias Latinas na versão final). ${ }^{15}$ A obra trataria dos temas de optimo statu civitatis e de optimo cive; Cícero informa ainda que dois livros já estavam prontos, efetivamente os atuais primeiros livros do De Re Publica. Os livros finalizados foram lidos para alguns amigos na sua villa em Túsculo, e criticado por um certo Salústio, que contrastou a dignitas histórica e exemplar dos personagens de 129 a.C. com a auctoritas política atual e contemporânea de Cícero, que fora um consular intimamente relacionado com as coisas da res publica $^{16}$ : a ficção histórica poderia retirar o impacto político da obra. Impressionado (commovit me) pela crítica, Cícero adotou a sugestão e alterou a obra para a data contemporânea (e, de fato, o futuro De Legibus tem como debatedores de Cícero, Ático e seu irmão Quinto), de modo que pudesse tocar diretamente em eventos políticos mais recentes, obra em que efetivamente o Arpinate comenta as ações políticos de contemporâneos como César, Pompeu, Clódio e Milo.

Independentemente de aderir-se ou não à interessante hipótese de Schmidt para a confecção do De Re Publica em dois planejamentos diferentes é certo que os dois tratados se

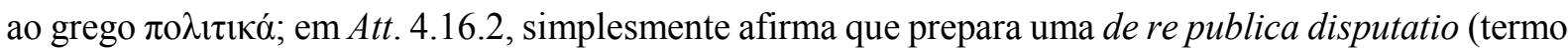
retomado em Rep. 1.13); e a importante carta $Q . F$. 3.5.1, também sem se referir a um título em específico, aponta sobretudo para as mudanças de concepção e planejamento da obra. Ver Schmidt, P. L. "The original version of the De Re Publica and the De Legibus" in Powell, Jonathan G. F.; North, J. A. Cicero's Republic: Bulletin of the Institute of Classical Studies, Supplement n. 76, 2001 p. 7-16.

${ }^{15} \mathrm{E}$, como enfatiza Schmidt, a mudança do planejamento de confecção fica evidente aqui. O primeiro plano de Cícero era uma obra de nove livros e uma discussão de nove dias. Ao final, Cícero concebeu um De Re Publica de seis livros e, ao que tudo indica, também um De Legibus de seis livros, ao que certamente incorporou questões novas que não estariam presentes no planejamento original (precisamente, para Schmidt: os livros 3 e 6 do De Re Publica e o livro 1 do De Legibus). Schmidt utiliza os "prefácios aristotélicos" a que Cícero faz menção como mapeamento para intercruzar o primeiro planejamento (uma obra de 9 livros) com o planejamento final (duas obras de 6 livros, ainda que uma tenha restado inacabada). Os livros 1,2 e 4 do De Re Publica seriam a primeira parte do planejamento original, seguido dos livros 2-6 do De Legibus e do livro 5 do De Re Publica. Para Schmidt, Cícero teria modificado o seu plano diante da situação insatisfatória de não poder comentar a política contemporânea no tratado se toda a discussão se travasse na data dramática de 129 a.C. - como apontado por Salústio, um ouvinte da primeira versão - e, igualmente, teria abandonado o De Legibus (livros 4-6, que continham reflexões institucionais concretas e pontuais) diante da turbulência dos anos 52-51 a.C. (a morte de Clódio; a defesa de Milo; a ruptura de Pompeu e César, e a guerra civil). Tais reflexões institucionais já estariam datadas no seu próximo período de otium forçado, quando ruma para obras como Academica, De Divinatione e Brutus.

${ }^{16}$ Cic. Q. F. 3.5.1, onde Cícero, recontando a intervenção daquele Salústio, descreve-se como "consularis et is qui in maximis versatus in re publica rebus essem". 
complementam. ${ }^{17}$ Em De Re Publica, em diálogo situado no século anterior (e apenas de modo superficial isso poderia parecer paradoxal), a pergunta em tela é como melhorar o estado de coisas na contemporaneidade, do mesmo modo que já em De Oratore se perguntava qual era o tipo de formação do perfeito orator. Em De Legibus, a persona ficta de Cícero se pergunta como funcionam as leis de uma res publica na sua melhor forma, erigindo assim - ao discutir os detalhes dessas normas, instituições, costumes e leges - critérios que permitiam fazer uma crítica do presente. ${ }^{18}$

O produto final De Re Publica contém seis livros e, com todo o seu vigor teórico e filosófico, é primordialmente um tratado preocupado com a orientação prática. De seu original resta-nos menos de um terço e é com este material que todos os comentadores e intérpretes precisam trabalhar. Em grossas tintas, uma descrição geral do tratado De Re Publica deve conter pelo menos o seguinte itinerário: os dois primeiros livros discutem a fundação e a conservação das cidades por meio da versão ciceroniana da "teoria das constituições", incluída a constituição mista; os livros três e quatro lidam com as instituições do governo e da sociedade ${ }^{19}$, inclusa uma grande discussão sobre a iustitia; os livros cinco e seis (este último, o Somnium Scipionis) são focadas no homem público, isso é, na importância das ações individuais dos que gerem a res publica. ${ }^{20}$

\section{${ }^{17}$ Cic. Leg. 2.14, "qui princeps de re publica scripsit idemque separatim de legibus eius".}

${ }^{18}$ Cf. Zetzel, 2013, p. 183, aponta que em todos os três diálogos, percebemos a ênfase que Cícero dá não diretamente aos tópicos retórica, política e direito, mas a relação desses tópicos com os indivíduos que efetivamente vivem e se guiam por eles: os oradores, os homens públicos, os cidadãos que compartilham normas entre si. Isso nos parece correto, desde que evitemos um excessivo esquematismo dos topoi de discussão ciceronianos: o rector do De Oratore é um homem público pensado para atuar em concretas civitates, aquelas mesmas reais debatidas em De Re Publica, que não deixa de ser um tratado que tangencia o direito público tanto quanto De Legibus - porquanto voltada às antiquitates, às institutiones, aos mores e às leges.

${ }^{19}$ Neste ponto parece residir - ao menos quanto aos fragmentos que restam - a força da hipótese de Schmidt colacionada supra. O livro terceiro do De Re Publica não guarda continuidade temática com o livro segundo, especialmente a discussão histórica dos mores, instituta e da disciplina de Roma, nem com o livro quarto, que parece tratar de uma avaliação das instituições romanas daquele tempo (veja-se os razoavelmente íntegros fragmentos Rep. 4.3 e 4.11-12). Schmidt entende as porções Rep. 2.64 e Rep. 4.3 como sequenciais; seriam incrementos posteriores o livro terceiro e as passagens Rep. 2.65-70 (que contém a analogia, bastante platônica, da concórdia dos ordines em uma cidade com a harmonia dos músicos em um mesmo coro).

${ }^{20}$ Dyck afirma que a estrutura do De Re Publica está assim dividida: discussão sobre de optimo statu civitatis (livros 1-2); de optimo cive (livros 5-6); e "os fundamentos éticos e humanos do optimus status e do optimus civis". Dyck, Andrew Roy. A Commentary on Cicero, De Legibus (Ann Arbor: University of Michigan Press, 2004), p. 98. Zetzel faz ainda outra consideração sobre a organização geral da obra: dentro dos três pares de livros, os ímpares lidam com questões teóricas mais gerais, e os pares lidam com as particularidades do mundo romano (a constituição dos romanos no livro segundo; as instituições dos romanos tais como a censura e a educação no livro quarto; as ações de um homem público romano diante das crises no livro sexto: Cipião Nasica, ao suprimir T. Graco). Para Zetzel, os livros 3 e 4 
Lélio percebe como duplo o escopo da discussão travada com Cipião (Rep. 2.21): na pretensão filosófica ou teorética há uma tentativa de descrever a lógica da sociedade política, dos pré-requisitos básicos e da estrutura institucional comum de governo; com um objetivo prático, a proposta de analisar especialmente o governo dos romanos, usando aspectos dessa estrutura teórica à luz da experiência histórica romana. Desse modo, Cícero consegue ao mesmo tempo fazer referência e se inserir na tradição sobre o pensamento filosófico político dos gregos, mas consegue também incorporar suas próprias ideias e direcioná-las explicitamente às suas preocupações políticas imediatas. $^{21}$

Com exceção do Somnium Scipionis e das citações esparsas e testemunhos em outros textos, o De Re Publica esteve perdido após a Antiguidade tardia. Numa história muito similar ao manual Institutiones do jurisconsulto Gaio (obra elementar de direito do séc. II d.C. perdida e reencontrada por Niebuhr em 1816 na Biblioteca de Verona), o De Re Publica de Cícero foi encontrado num palimpsesto na Biblioteca do Vaticano em 1819, sendo então novamente editado em 1822 pelas mãos do cardeal Angelo Mai. ${ }^{22}$

começam com uma discussão da base do direito natural (livro três) para então aplicá-la à estrutura do governo romano (livro 4), vide Zetzel, 2013, p. 184-187; Embora a descrição dos pares seja adequada em geral, os livros terceiro e quatro não nos parecem formar "um par" em conteúdo, ainda que a estrutura de prefácios (nos livros 1, 3 e 5) seja um bom argumento para esta visão de estrutura. Parece-nos ainda que Zetzel erra a mão ao enxergar no mos maiorum e nos instituta romanos fontes normativas e instituições sociais "não positivas" e, com isto, fazê-las derivar necesariamente do direito natural. O fato de não serem mapeáveis no tempo e no espaço ou positivadas - como uma lex promulgada num comitium - não significa que tais instituições derivem ou correspondam necessariamente a uma noção ética de direito natural; não é assim na common law britânica, tampouco o era no direito costumeiro dos romanos. Sem dúvida o que vem dos antigos era venerável para um romano como Cícero: afirmar, no entanto, a plena conformidade de todo o passado com a natureza (e com esse direito do cosmos) é um outro passo que, ao menos no De Re Publica, Cícero não dá. O excessivo paralelo entre as "instituições históricas da moralidade romana e da tradição ética grega" é uma interpretação possível dos fragmentos, mas não de todo defensável. O que não significa que moral individual e instituições não se liguem em Cícero: há um balanço íntimo e constante entre ambas, no que concordamos plenamente com Zetzel. Apenas não nos parece que haja direta transcrição das instituições éticas com as instituições romanas; em Cícero, parece-nos, as instituições têm suas próprias histórias e méritos, independentemente de responderem a uma teoria a priori.

${ }^{21}$ Assim, mesmo que Cícero aceite v.g. a forma básica da teoria do sexto livro das Histórias de Políbio a respeito dos seis tipos de constituição, do ciclo de anacyklosis e a superioridade de uma constituição mista, sua descrição de como as coisas funcionaram é diversa, tampouco acreditando Cícero no fado da ordem cíclica de Políbio. Em Rep. 2.27, considera-se Políbio antes de mais nada um conhecedor da história, de seus fatos e datas memoráveis romana (e alguém íntimo do interlocutor, Cipião), do que propriamente um teórico fundamental da política.

${ }^{22}$ Trata-se do Palimpsesto Vaticano (Vat. lat. 5757; ou, CLA I 35 nos Codices Latini Antiquiores). O texto original do códice data do final do século IV (Ziegler) ou século V (Powell) e foi reutilizado no século VII para a cópia de um comentário de Agostinho aos Salmos 119 a 140. Dos cerca de oitenta cadernos que compunham o códice (e, presumivelmente, continham os seis livros do De Re Publica), restaram 28 cadernos incompletos (dos livros I-III) e 5 fólios (dos livros IV-V). Ziegler identificou, por sua vez, a presença de dois escribas diferentes no palimpsesto original do tratado, e de um revisor que 
Fugiria aos limites deste texto - e da competência de seu autor - uma reflexão a respeito da transmissão do texto De Re Publica ao longo da Idade Média e do Renascimento ou de suas múltiplas interpretações. É certo que, no entanto, o De Re Publica soma às dificuldades de estabelecimento e correção do texto um desafio a mais: destacá-lo (ou, pelo menos, não o vincular imediatamente) das interpretações que dele fizeram autores medievais como Agostinho ou Lactâncio. Temos os livros primeiro e segundo disponíveis em boas porções, ainda que com suas lacunas; e o sexto livro, o Somnium, que seguiu toda uma tradição de transmissão própria. Os livros 3 a 6 - inclusive o livro terceiro, tremendamente citado por conta da emulação dos discursos do acadêmico Carnéades em 155 a.C. - precisam ser levados em conta no conjunto da obra, mas a grande porção de transmissão indireta não pode ser olvidada. Muitas interpretações a respeito do "estoicismo" de Cícero e análises apressadas a respeito do seu jusnaturalismo e sua concepção de iustitia parecem ser guiadas antes pela percepção do cristão Lactâncio do que pela estrutura geral dos argumentos do De Re Publica. ${ }^{23}$

realizou trabalho detido. Em referência à questões de edição, o Somnium Scipionis é um texto à parte do Vat. lat. 5757; possui pelo menos cinco códices próprios, além dos Codice Commentarii in Somnium Scipionis de Macróbio de finais do século IV, uma obra registrada em centenas de manuscritos medievais distintos. O Palimpsesto Vaticano $(=V$.) está acessível na Biblioteca Digital do Vaticano, disponível em: < https://digi.vatlib.it/view/MSS_Vat.lat.5757 >, consultada para estes fins. Acesso: 12 abr. 2018.

${ }^{22}$ Para isso, remetemos o leitor a Kempshal, 2001.

${ }^{23}$ Parece-nos ser particularmente importante enfatizar isto quanto ao livro três. Mesmo com as parcelas legíveis em $V$., o livro terceiro é profundamente devedor de Agostinho, Ambrósio, Tertuliano, Isidoro e Lactâncio. São de Lactâncio - e exclusivamente de seus Divinarum institutionum libri - as passagens Rep. 3.2, 3.9-11, 3.19-22, 3.28-31, 3.40 e a famosa definição da vera lex como recta ratio de Rep. 3.33 (Rep. 3.33 = Lact. DI 6.8.6-9). O problema reside na excessiva passividade com que os intérpretes leem tais passagens. Em um texto extremamente técnico e refinado a respeito das passagens envolvendo Carnéades, Glucker entende por bem distinguir tanto um "Carnéades de Cícero" quanto um "Cícero de Lactâncio". Glucker interpreta que, em grande medida, o discurso de Carnéades era dirigido contra o ius naturale concebido pelo estoicismo de Crísipo (não contra, como disse Lactâncio, a concepção platônica ou aristotélica, em Rep. 3.29-31; o discurso de Carnéades naquele momento distingue populorum instituta et leges do ius naturale). No exemplo oferecido por Glucker: Lactâncio equivocase ou altera o sentido do texto, compreendendo o discurso e Carnéades contra "Aristoteles et Plato" (ao invés de contra o estoicismo antigo) mesmo tendo à disposição um enxerto do texto de Lélio; ele não apenas não procedeu a uma adequada apreciação dos argumentos de Filo-Carnéades, contra quem se destinavam, como erroneamente os atribui a filósofos que conhecia pouco quanto à economia textual ("assumindo" argumentos de Platão e Aristóteles. Diante disso, Glucker chama a atenção para a questão raramente levantada da credibilidade ou fidedignidade de Lactâncio. O autor chega à conclusão de que, (i) por vezes, Lactâncio opta por uma "leitura superior" ao invés da tradução do manuscrito; (ii) em outras ocasiões, ele altera a ordem, ignora termos, substitui palavras, atualizando para o latim de sua própria era. Cf. Glucker, John. "Carneades in Rome - some Unsolved Problems" in Powell, Jonathan G. F.; North, J. A. Cicero's Republic: Bulletin of the Institute of Classical Studies, Supplement n. 76, 2001, p. 67-72. Tomamos o estudo de Glucker - muito mais complexo e aqui grosseiramente resumido - como um lembrete singelo de que a análise histórica, que nasce do trabalho com as fontes, precisa ter o cuidado de não naturalizar o que assume vestes canônicas. Essa dose de ceticismo (que Carnéades talvez aprovasse) é importante na medida que enxertos como Rep. 3.19-22 e Rep. 3.33 são 
Isto não significa aqui a reivindicação de uma exegese vã pelo "verdadeiro Cícero" - e, de fato, é melhor que tenhamos um texto difícil e fragmentário gerando dúvidas do que texto algum, a certeza do silêncio. Todavia, muitas incompreensões a respeito do texto ciceroniano são geradas se os comentários, acréscimos e interpretações dos autores medievais são incorporados acriticamente prima facie. Se é correto que cada época pode ter sua interpretação, é justo que nossa leitura de Cícero esteja liberta pelo menos de certos bordões datados.

\section{A definição de res publica de Cipião Emiliano em Rep. 1.39}

Como exprimiu Konrat Ziegler, um dos seus mais importantes editores modernos diante da tarefa de justificar as opções de estabelecimento de um texto com um único e lacunoso palimpsesto sobrevivente, um comentário não desprovido de certo bom humor -, o tratado $D e$ Re Publica não está exatamente entre os mais fáceis dos escritos do Arpinate. ${ }^{24}$ Mesmo o estudioso e o leitor despreocupados com as questões de reconstituição textual não estão a salvo das corrupções e das falhas de continuidade do texto, além da dificuldade paritária no emprego de termos latinos de múltiplas e difíceis acepções. Nosso objetivo é, primeiro, apresentar a definitio de Cícero para o termo (Rep. 1.39) situando-a dentro do tratado; ainda, discutir a sua relação com outros termos - populus, ius, consensus, utilitas, communio e societas-; e, com isto, apresentar uma possibilidade de interpretação para a definição de res publica. Embora sejam comuns na literatura específica os avisos gerais a respeito das "dificuldades de tradução" de termos como res publica não raro se percebe a tendência de interpretações apressadas de passagens não evidentes per se para justificar uma dada posição (prévia) de interpretação a respeito de Rep. 1.39. Qualquer que seja a conclusão superveniente, tentar fundamentá-la à luz do pensamento de Cícero é um ônus inescapável.

frequentemente invocadas automaticamente para estabelecer como óbvias algumas interpretações do tratado ciceroniano que talvez estejam em aberto. Como gracejou certa vez em um de seus livros o escritor Frank Herbert, o maior defeito dos historiadores é não se dar por satisfeitos.

${ }^{24}$ Ziegler, Konrat. "Zu Text und Textgeschichte der Republik Ciceros" in Hermes, vol. 66. Bd., H. 4, 1931, p. 280. 
De Re Publica disputatio: qual é a discussão republicana de Cícero?

Não é sem alguma ironia que o tratado De Re Publica, sempre memorado por seu caráter fragmentário, já se inicie com uma lacuna ${ }^{25}$; segue-se a ela um prefácio com a voz do próprio Cícero (Rep. 1-13), incluindo uma transição que justifica a continuidade da discussão a partir do diálogo filosófico e, assim, contendo a apresentação do cenário, da data dramática (as feriae Latinis de 129 a.C.) e das personagens presentes no primeiro dia de discussões (Rep. 1.14-17). Em Rep. 1.13 (bem como adiante, em Rep. $2.65^{26}$ ) a análise se circunscreve por fim no grande objeto do primeiro dia de discussões (Rep. 1-2), a fundação e a conservação de comunidades políticas citadinas, a virtude social que aproxima o homem dos deuses.

Peter Schmidt nomeou o trecho de Rep 1.1-13 "ad rem publicam capessendam" e, acertadamente, deu grande relevância à praefatio dentro das composições de Cícero tanto no De Re Publica quanto no De Legibus. ${ }^{27}$ Elementos importantes para compreender globalmente o tratado estão de fato ali apresentados. A passagem de texto contém, por um lado, a frequente ideia ciceroniana de que a filosofia tem papel cultural civilizador dentro do ambiente público e político da res publica, de seus cidadãos e oradores ${ }^{28}$; via de mão dupla, a valorização da

\footnotetext{
${ }^{25}$ Faltam dois primeiros cadernos inteiros, mais um fólio do caderno terceiro. A edição de Ziegler avoca para esta lacuna sete fragmentos que poderiam fazer parte do trecho perdido (os autores: Plínio, o Jovem [I d.C.], o gramático Nônio Marcelo [IV-V d.C.], o apologeta cristão Lactâncio [IV d.C.] e o gramático Arusiano Méssio [IV d.C.]). Os fragmentos de Plínio mencionam o hábito ciceroniano de nomear os filósofos gregos quando segue seus pensamentos. A passagem de Lactâncio (fr.1e) se coaduna com Rep. 1.7, 1.9 e 1.11, e o fragmento fr.1a de Nônio com Rep. 1.8. O fragmento fr.1f de Nônio também poderia pertencer ao excurso sobre os tipos de consilii tanto no livro primeiro quanto segundo; se considerado adequadamente inserido neste ponto, contudo, a referência à necessidade consiliis et disciplina para o sucesso histórico de Cartago (e, presumivelmente, de toda res publica que os possua) serve de imagem que antecipa a pergunta primordial do tratado.

${ }^{26}$ E se a tese de Schmidt estiver correta e o fragmento Rep. 2.65 (até 2.69) não tiver integrado os dois tomos na sua primeira redação, a assertiva não se modifica; na sua versão revisada (posto que Rep. 2.65 faz parte de $V$.), ao fazer a transição da discussão para o livro terceiro, Cícero enfatiza uma vez mais que civitates condere aut conservare (Rep. 1.13, correspondendo ao de instutiendis et conservandis civitatibus de Rep. 2.65) fora o tópico de discussão (disserendi locum).
}

${ }^{27}$ Schmidt, 2001, p. 14.

${ }^{28}$ Eis o munus rei publicae de Cícero, expressão tomada de De Div. (2.4), mas de algum modo presente neste prefácio (Rep. 1.12). Por um lado, a filosofia é serviço de abertura intelectual e cultural daquilo que antes só estivera disponível aos que conheciam bem a língua grega; por outro, oferece uma contínua oportunidade de participação na vida política (Schmidt, 2001, p. 14) mesmo em períodos de otium. Vide Lima, Sidney Calheiros de. "Cícero e a obra filosófica em latim como munus rei publicae" in: Nuntius Antiquus, n. 5, 2010, p. 93-102, e p. 94 nt. 4 (especificamente a respeito do De Re Publica); Lima, 2009, p. 197-200 (a respeito da pretensão ciceroniana de illustrare a filosofia latina); p. 501 (a respeito da proposição em Rep. 1.19 da importância do conhecimento filosófico - especialmente da physis também para a política). 
filosofia não deixa de lado a ênfase pela vida política ativa, de modo que também o sapiens deve exercitar a arte política. Anuncia aquilo que há de mais divino na virtude que os homens a despeito de suas falhas podem praticar (quam civitatis aut condere novas aut conservare iam conditas, presente em Rep. 1.12-13, retomado em Rep. 2.65), um princípio relevantíssimo para a compreensão posterior da definição de res publica. Assinala ainda que a experiência (memoria) romana inclui número suficiente de homens concretos, competentes na arte de guiar (in gerenda) a res publica (os clarissimi ac sapientissimi nostrae civitatis viri mencionados em Rep. 1.13) - conhecimento passado que torna factível uma "de re publica disputatio". Se a discussão realmente se inicia - do ponto de vista dos conceitos, da argumentação e dos exempla romanos - junto com o diálogo filosófico ${ }^{29}$, cabe à exortação inicial a ligação diacrônica entre o pensamento dos ilustres representantes da nobilitas diante dos dilemas de 129 a.C. com aqueles da década de cinquenta em que Cícero escrevia. Isto porque embora seja um texto filosófico em sentido estrito, o De Re Publica não é apenas trabalho de deleite intelectual, mas de contribuição para os negotia públicos. ${ }^{30} \mathrm{~A}$ mímesis do diálogo pode até resultar, em certa medida, em uma ficção histórica (e uma representação fidedigna de suas personagens ${ }^{31}$ ), mas uma que possui um fito prático contemporâneo apreensível aos seus leitores.

${ }^{29}$ O diálogo filosófico ciceroniano se constitui tanto como um relato probabile, verosimile, bem acomodado (comodissime). Para tal tópico, sugerimos ao leitor cf. Lima, Sidney Calheiros de. Aspectos do gênero dialógico no De Finibus de Cícero. Tese (Doutorado em Linguística, Área de Letras Clássicas - Instituto de Estudos da Linguagem, UNICAMP, 2009), p. 112-124.

${ }^{30}$ Bem entendido, no entanto, que seria forçar a leitura enxergar uma oposição totalizante em Cícero entre trabalhos "intelectuais" e "práticos", ou ainda, frutos do otium ou destinados apenas ao negotium. Mesmo no texto que ora nos interessa uma das personagens - Filo, um dos principais debatedores de Cipião - deixa entrever o argumento de que o conhecimento teorético (como aquilo que os filósofos helênicos consideravam Física) não é conhecimento desprovido de importância na formação de quem atua no mundo público ou de quando se discute a política. Diante da provocação de outro personagem importante, Lélio - devemos compôr um interdito a respeito do misterioso segundo sol?, ri-se -, Manílio recorda que é o próprio autor da zombaria um dos mais excelentes nesta ars. (Cic. Rep. 1.19-20). Cícero pontua a mesma ideia no seu "catálogo filosófico" (Cic. De Div. 2.1) e em vários prefácios (v.g. Tusc. Disp. 1.1; De Fin. 1.1-10). A posição de Cícero é provocativa: primeiro porque nega a dicotomia grega entre a vida ativa e a vida contemplativa, e mesmo a polaridade romana entre o otium e o negotium; segundo, porque mantém viva a ideia de res publica que Cícero tece ao longo de sua vida, e serve para conectar a figura do filósofo a homem público e orador. Ver Schofield, Malcolm. "Writing philosophy" in Steel, Catherine (editor). The Cambridge Companion to Cicero (Cambridge: Cambridge University Press, 2013), p. 73-75.

${ }^{31}$ O centro do diálogo está na figura de Públio Cornélio Cipião Emiliano Africano [Menor] Numantino (c. 185 - 129 a.C.). Era filho natural de Lucío Emílio Paulo, famoso por derrotar o rei Perseu da Macedônia; e filho adotado por Públio Cornélio Cipião Africano, responsável pela vitória sobre Cartago e recordado ainda, evidentemente, como um dos líderes da oposição senatorial aos Graco. Os modernos, a partir de Cícero, leem Cipião como figura patrona do intelectual "Círculo dos Cipiões", como uma incipiente vertente helenizante do século II a.C. Cf. Zetzel, James E. G. "Cicero and the Scipionic Circle" in: Harvard Studies in Classical Philology, vol. 76, 1972, p. 173-176. Os outros personagens são: Gaio Lélio Sapiens, famoso orador, também ex-cônsul, que comparece acompanhado de seu genro, 
O problema prático - da data de 129 a.C. ${ }^{32}$ e dos próprios tempos de Cícero - é introduzido de forma casual no prelúdio, quando os amici de Cipião Emiliano (oito ao total: quatro seniores e quatro juniores) se encontram na villa de Cipião, durante as férias latinas, e iniciam a conversa a partir dos rumores astronômicos do avistar de dois sois. É assim que Lélio, o amigo de Cipião, provoca: por que tratar de dois sois quando questões maiores se exsurgem, quando in una republica virtualmente existiam dois senados e dois povos distintos (una re publica duo senatus ... populum unum in duas partis, Rep. 1.31) após o agitado tribunato de Tibério Graco, opondo boni viri aos sediciosos?

É através de Lélio (Rep. 1.31-33) que a motivação daquela disputatio aparece: o estudo a respeito da res publica - do melhor tipo, e de suas características - serve acima de tudo para melhor compreensão da situação presente, com visas à solução das questões colocadas em seu tempo. Desde logo encontramos uma das ambivalências do termo res publica: é o arranjo institucional de uma civitas, como Cipião explicará adiante, uma comunidade política; também é para Lélio a coisa comum, aquilo que interessa a todos os "condôminos" da vida pública e política. A situação da res publica é grave, mas não irremediável - não estamos diante do fado do ciclo polibiano -, e é possível tornar o Senado e o populus um só novamente (Rep. 1.32). O evento astronômico dos dois sois serve assim de símbolo para a divisão perniciosa da res publica em duas partes ${ }^{33}$; divisão esta vertical, opondo uma parte do Senado e do povo que quer preservar a res publica, e a outra porção que age de modo a comprometê-la e destruí-la.

o jurisconsulto Gaio Fânio, por Espúrio Múmio (que fora censor e repetidamente um aliado militar de Cipião) e pelo célebre Quinto Múcio Cévola Áugure. Participam ainda do diálogo o amigo de Cipião Lúcio Fúrio Filo, ex-cônsul; o sobrinho de Cipião, Quinto Élio Tuberão, tribuno da plebe no ano anterior; Públio Rutílio Rufo, também ex-cônsul, reputado como orador, jurista e conhecedor da filosofia estoica; e, por fim, o jurisconsulto Mânio Manílio, ex-cônsul, o mais velho ancião presente. Este breve apanhado não se presta a uma doxografia: é de se salientar, no entanto, que Cícero escolheu apenas alguns dos nomes mais relevantes das gerações que se encontravam ativas em 129 a.C.; todos os personagens são minimamente familiarizados com os escritos gregos de história e filosofia - o que não era um padrão no século de Cipião -, bem como com a história e as instituições romanas. Também não é por acaso existirem tantos consulares.

${ }^{32}$ A data escolhida evocada a época das conquistas externas e consolidação de Roma, com a derrota de Cartago no norte da África, a tomada de Corinto na Grécia e a Numância na Hispânia. No plano doméstico foi uma época conturbada e pontilhada por disputas entre grandes personalidades: a lex Sempronia dos Graco assombra o texto.

${ }^{33}$ Cícero não é Tácito: como Lívio, ainda que por diferentes caminhos, para Cícero a marca da res publica em seu estado saudável é a concórdia entre os ordines (especialmente, para Cícero, após as turbulências das guerras sociais e dos conflitos civis entre Mário e Sila, as heranças que marcaram os seus anos de formação), o funcionamento regular das instituições e magistraturas, e a observância, ao menos geral, dos costumes que regem a vida pública. 
Com a proposta de discussão de Lélio - reverter o discurso para a política - aprovada pelos demais seniores presentes, Lélio cita as credenciais de Cipião para discutir a respeito da coisa pública (Rep. 1.34: quod erat aequum de re publica potissimum principem reipublicae dicere) e que Cipião, além desta experiência e prática na vida política, frequentemente ouvira a respeito da política o historiador Políbio e o estoico Panécio ${ }^{34}$; Filo acrescentará adiante seus muitos feitos em prol da res publica (Rep. 1.37).

Cipião aceita o encargo e diz algo a respeito da própria necessidade de uma definitio antes de apresentar a sua. Trata-se de um limite, um acerto comum da linguagem, uma vez que, está ciente, o termo res publica é amplo; entre os ilustres varões que lidavam diariamente com as coisas públicas, pensava Cipião, a realidade da res publica era evidente, cabendo assim à definição apenas aparar as arestas terminológicas. ${ }^{35}$ Neste momento do diálogo Cícero aproveita a ocasião, vez mais, para refletir sobre a diferença entre o modo como tratará o tema em relação aos seus precedentes gregos. ${ }^{36}$ Assumida a definição de res publica, caberia ao restante da discussão - ou, ao restante do tratado - esmiuçar as características e qualidades de uma organização deste tipo. É importante destacar que a definição que se seguirá não é

\footnotetext{
${ }^{34}$ Asmis indica que devemos levar a sério o uso do termo rogare por Lélio para se dirigir a Cipião: é o típico termo das reuniões senatoriais; após o início do debate da matéria, seguia-se ao ato de rogare sententiam aos membros do Senado, iniciando-se pelo princeps senatus, função representada no diálogo por Cipião, princeps rei publicae. Além disso, mesmo que Cícero esteja aqui seguindo um certo gênero de escrita - o diálogo filosófico -, é uma particularidade sua a ênfase das personagens, desde o começo, na utilidade prática da discussão (o Sócrates de Platão não está tão preocupado, como Cipião ou Lélio, com o "depois" - o debate basta em si mesmo). Vide Asmis, Elizabeth. "The State as a Partnership: Cicero's Definition of Res Publica in his work On The State" in: History of Political Thought, vol. 25, 2004 , p. 571-573. Sendo assim, mesmo o debate filosófico - inspirado numa obra como a Politeia platônica - não deixa de responder ao decoro e à ritualística juspublicística costumeira dos romanos (adequada, ademais, ao currículo político dos interlocutores).

${ }^{35}$ Cícero já empregava definições iniciais em De Inv. (2.53), bem como justifica seu emprego De Or. (1.189-190: est enim definitio rerum earum, quae sunt eius rei propriae, quam definire volumus, brevis et circumscripta quaedam explicatio). Está de acordo com a anotação de Cícero a respeito do uso das definições no De Fin. (2.3-5) no Fedro de Platão (237b-e, 263a-d): uma palavra como "amor", ao contrário de termos como "prata" ou "ferro", possui uma ambiguidade inata e inerente que deve ser solucionada pelo fornecimento de premissas precisas.

${ }^{36}$ Cipião não deseja definir a res publica a partir de elementos de sua origem (como Platão e especialmente Aristóteles) nem se perde em taxonomias mais elaboradas. Pontua um contraste entre o tratamento do tema pelos docti e os prudentes, est'últimos que possuem sabedoria prática, a quem claramente se alinha. Mesmo a história de Roma do livro segundo será antes uma história da experiência do que uma análise teórica): Cipião ainda sugere que seus ouvintes, justamente por se filiarem aos prudentes, possuem um grande entendimento prévio da realidade política. A definição se justifica pela ambiguidade do termo e para fornecer explicitamente as premissas.
} 
abandonada ao longo de todo o excurso ${ }^{37}$ : "res publica, res populi" é a definição que continua iluminando toda a discussão subsequente, especialmente nos livros primeiro e segundo.

A definição de Cipião em Rep. 1.39

Feita a exortação inicial de um debate sobre a res publica, i.e. sobre a fundação e conservação de civitates, e a competência de eminentes nobiles da história romana para refletir sobre tal experiência (Rep. 1.12-13), e estabelecida a premência política do debate (Rep. 1.32$34,1.38)$, por fim, passemos à definiç̧ão de Cipião ${ }^{38}$ :

[De Re Publica - Lib. I] 25.39. 'Est igitur,' inquit Africanus, 'res publica | res populi, populus autem non omnis hominum coetus quoquo modo congregatus, sed coetus multitudinis iuris consensu et utilitatis communione sociatus, eius autem prima causa coëundi est non tam inbecilitas quam naturalis quaedam hominum quasi congregatio; non est enim singulare nec solivagum genus hoc, sed ita generatum ut ne in omnium quidem rerum affluen $<$ tia $>$. [Excidit quaternionis VIIII. folio secundum] idque ipsa natura non invitaret solum sed etiam cogeret (Non, p. 321, 16). ${ }^{39}$

${ }^{37}$ A definição tem também a função de acertar as premissas do debate. A primeira definição não é discutida: res publica em Cícero será sempre res populi, no sentido de que qualquer ouvinte razoável deveria concordar com ela.

${ }^{38}$ Embora sejam semelhantes, apresentamos a edição Konrat Ziegler (1 $1^{a}$ edição, 1915) no corpo do texto e, em seguir, nesta nota, a edição de Angelo Mai (1822). "[DE RE PVBLICA - Lib I] XXV. 'Est igitur, inquit Africanus, res publica | res populi', populus autem non omnis hominum coetus quoquo modo congregatus, sed coetus multitudinis iuris consensu et utilitatis communione sociatus. Eius autem prima causa coeundi est non tam inbecilitas quam naturalis quaedam hominum quasi congregatio: non est enim singulare nem soliuagum genus hoc, sed ita generatum, ut ne in omnium quidem rerum afluent-\|tia ... [Desiderantur paginae duas]. - Quid est res publica, nisi res populi? Res ergo communis, res utique ciuitatis. Quid est autem ciuitas nisi multitudo hominum in quoddam uinculum redacta concordiae? Apud eos enim ita legitur 'Breui multitudo dispersa atque uaga, concordia ciuitas facta erat', Augustinus epist. CXXXVIII.10.(4)" (o texto de Agostinho é uma anotação da edição de Mai, não do palimpsesto ver Mai, Angelo. M. Tulli Ciceronis De Re Publica quae supersunt (Roma: Collegio Urbano apud Burliaeum, 1822), p. 69-70 [Rep. 1.25=1.39]. No Vat.lat. $5757(=V$.) o texto encontra-se nas p. 61-62. Podemos acrescentar ainda que o fragmento Rep. 1.39 representa em $V$ um caput (precisamente do fólio 9); a divisão em capita é comum na tradição de textos ciceronianos (e já existia, de fato, antes dele nos textos jurídicos romanos). Seguimos a sugestão de Butler de que tal divisão não se dá meramente por critérios estilísticos, mas de conteúdo: uma pausa que convida o leitor a refletir sobre o que fora enunciado até então (simples "blocos de texto" sem capitulação impossibilitariam causar ao leitor os efeitos reflexivos que um orador pode provocar em seu ouvinte por outros meios). Considerada a capitulação uma marca distintiva do texto escrito, ou mesmo um paratexto, isso nos leva a concluir não apenas que o Arpinate pretendia ser lembrado não apenas como grande orador, mas nas complexidades da arte escrita, mas que a própria materialidade do texto indica que a definitio de Rep. 1.39 merece ser destacada. Ver Butler, Shane. "Cicero's capita" in Jansen, Laura (ed.). The Roman Paratext: frame, texts, readers (New York: Cambridge University Press, 2014), p. 92-102.

39 Texto da edição Ziegler, Konrat. Marcus Tullius Cicero: De re publica, librorum sex quae man serunt (Lepzig: Teubner, 1915), p. 24-25. A integração com o texto de Nônio é proposta deste editor. 
É útil considerar desde logo, como fez Schofield, que existem dois componentes centrais nesta passagem: primeiro, a definição de res publica como res populi; ao que se segue, evidentemente, à necessidade de definir populus: multidão congregada de homens qualificadamente associada (sociatus) pela existência de um iuris consensus e de uma utilitatis communio. Cícero não se dá ao trabalho de esmiuçar o emprego da palavra amplíssima palavra res, contentando-se em fazer derivar a res publica da definição de populus. Percebe-se desde logo que não só res publica e populus são termos centrais na passagem, mas também iuris consensus, utilitatis communio e sociatus (em distinção a congregatus), que melhor explicam o populus; esses mesmos termos são relevantes para o tratamento ciceroniano do consilium e para a elaboração da teoria das constituições. Se quiséssemos aplicar a linguagem dos predicados de primeira ordem poderíamos assim descrever: uma res publica (R) é res populi, algo que pertence ao populus (P); o populus existe enquanto tal se, e somente se, tal associação estiver duplamente qualificada pelo iuris consensus (IC) e pela utilitatis communio (UC); é a essa totalidade de definição que Asmis adequadamente chamou de pacote etimológico. ${ }^{40}$

Em termos filosóficos a definição de Rep. 1.39 nos informa que há que se distinguir entre um gênero mais amplo de ajuntamento de homens (omnis hominum coetus ... quoquo modo congregatus) e a sua forma qualificada, uma associação (sociatus) marcada pelo consensus e pela utilitas. Nenhuma surpresa: Cipião informara no fragmento anterior que não iria realizar uma genealogia da res publica em outros grupos primeiros (como a família, a gens ou as tribos romanas). Estritamente falando a gênese da comunidade política de que trata Cipião já pressupõe um mínimo civilizacional, que existam condições para que os homens se congreguem, e mais, condições tais que o façam de um modo distinto, qualificado, formando a entidade do populus. Pouco adiante, em Rep. 1.41, Cipião recapitula a sua definição de res publica contrastando-a com os termos urbs, oppidum e civitas (e ainda, status civitatis, termo aqui bastante sentido do significado geralmente atribuído ao termo no direito privado), que vai se tornar a palavra de maior proximidade com res publica. ${ }^{41}$ Os homens unem-se em

${ }^{40}$ Asmis, 2004, p. 577.

${ }^{41}$ Cic. Rep. 1.41. "“*<quae $>$ dam quase semina, neque reliquarum virtutum nec ipisius rei publicae reperiatur ulla institutio. hi coetus igitur hac de qua exposui causa instituti, sedem primum certo loco domiciolorum causa constituerunt; quam cum locia manuque saepsissent, eius modi coniunctionem tectorum oppidum vel urbem appellaverunt, delubris distinctam spatiisque communibus. omnis ergo populus, qui est talis coetus multitudinus qualem | exposui, omnis civitas, quae est constitutio populi, omnis res publica, quase ut dixi populi res est, consilio quodam regenda est, ut diuturna sit. Id autem consilium primer semper ad eam causam referendum est quase causa genuit civitatem". Nesta recapitulação - fragmento que, em verdade, introduz o que partir de Rep. 1.42 se converte na versão ciceroniana da teoria das constituições -, res publica equivale a uma constitutio populi (Rep. 1.41) que se rege ou dirige por algum consilium. Já optimus status civitatis é expressão que surge no final do livro 
fortificações e cidades para viver em espaços comuns: mais do que a convivência comum (o fato de coabitarem uma urbs), contudo, é a organização estruturada e funcional de uma civitas que, se pertencer a um populus, traduz-se em res publica. ${ }^{42}$ Pode-se dizer que toda res publica opera numa civitas (um dado populus - deve haver iuris consensus e utilitatis communio -, organizado por um certo consilium, em certo território, com um conjunto comum de regras), mas que o conceito de res publica possui um significado técnico que especifica a própria civitas. Perceba-se que em ambas as passagens a res populi não parece ser tratada assim como sucedânea, mas sim, como contemporânea à existência de um povo: quando a multidão de homens se organiza de maneira tal a satisfazer as condições do iuris consensus e da utilitatis communio (e, assim, já está vivendo em uma civitas) ela já é titular dessa mesma res que é o cerne da res publica. ${ }^{43}$

primeiro (Cic. Rep. 1.70-71) e serve de referência no livro segundo (Rep. 2.39); a palavra status aparece em outros momentos, bem como a variante status rei publicae. Evidentemente status não pode ser traduzido por "Estado". As traduções anglófonas optam, por vezes, por state, mas essa opção só é válida se, como fez Zetzel (1999, p. xxxviii), pontuar-se que civitas e status civitatis não são equivalentes aos Estados Nacionais modernos; noutros casos optam pela palavra commonwealth (que é, no entanto, outro termo intraduzível e peculiar). E o status civitatis não diz respeito aqui à situação jurídica de um indivíduo dentro do ordenamento como no direito privado romano. Status representa simplesmente "forma", "estrutura", "modo de organização" da entidade res publica, da civitas.

${ }^{42}$ Civitas também é uma palavra ambivalente em toda a literatura latina, e por vezes corresponde à res publica de Rep. 1.39. Como notou Ando, civitas correntemente traduz uma relação metonímica entre a comunidade política (em Cícero, portanto, res publica como res populi, englobando consensus e utilitas) e a extensão territorial, populacional e o conjunto normativo de uma dada cidade, ligado a um solum (patriae). Enquanto nas Verrinas (Verr. 2.2.32) Cícero utiliza o termo no sentido territorial, em De domo sua (78) civitas representa ainda o conjunto de prerrogativas de um civis (para os modernos, da "cidadania"). Ver Ando, Clifford. Roman social imaginaries: language and thought in contexts of Empire (Buffalo: University of Toronto Press, 2015), p. 7-11, 17-23.

${ }^{43}$ Intérpretes como Schofield - principalmente ele -, Wood e Atkins partem suas análises de Rep. 1.39 a partir da ideia da "metáfora da propriedade". Especialmente para Schofield, as passagens entre Rep. 3.43-46 se voltariam a esta linguagem para demonstrar como sob as formas degeneradas da tirania, da oligarquia e do governo da multidão a res não "pertence" ao povo. Parece que é imprecisa a crítica de Asmis à interpretação de Schofield: o autor não fala em momento algum que se trata efetivamente de uma propriedade tal qual um conjunto imobiliário ou de ativos que pertencem à causa comum (cf. Asmis, 2004, p. 587, nt. 57). Haveria res publica e populus, interpreta Schofield, quando o povo pode vindicar (vindicare) aquilo que é seu (ius suum tenere), especialmente a libertas. Se o populus possui sua própria res (a res populi, a res publica), disso se segue que terá os direitos [políticos] de seu uso e administração; a liberdade política do cidadão romano consiste precisamente no exercício desses direitos de usar e gerir o que é próprio do populus, o que é sua res. A linha de pensamento de Schofield não é disparatada, mas ela extrapola os conceitos utilizados por Cícero - que não menciona então libertas em Rep. 1.39; e em Rep. 3.45, quando utiliza o termo, não está fazendo propriamente um conceito de libertas, mas utilizando-o para enfatizar a perda do direito de provocatio no tempo dos decênviros - e o que parece ser a estrutura do tratado. De fato, em Rep. 3.43, Cipião aponta a ausência de um unum vinculium iuris nec consensus ac societas coetus (= populus); em Rep. 3.54, Lélio enfatiza que nas formas viciosas de gerência da comunidade política inexiste o consensus iuris que fora utilizado por Cipião na sua definição anterior. É claro que Schofield está correto ao afirmar que a liberdade é uma característica do populus e da res publica (não é sem razão que a narrativa do livro segundo enfoca a 
A definição contida em Rep. 1.39 certamente soaria mais familiar aos seus ouvintes romanos do que a nós. Cícero não sente necessidade de definir iuris consensus, utilitatis communio, hominum coetus, societas ou congregatus [hominum]. É o que nos resta tentar fazer com uma separação meramente formal de Rep. 1.39 para a análise. Começaremos pelos dois elementos qualificativos de populus, o iuris consensus e a utilitatis communio; e embora os dois termos invoquem questões distintas de interpretação (aos quais trataremos um por um), assinale-se que ambos dois qualificativos são de equivalente importância na definitio, como implica a conjunção aditiva et (2.2.1). Diante destas questões, será possível tratar da interpretação da res publica de Cícero em seu balanço entre a associação por "natureza" (natura, que se opõe a inbecilitas) e, doutro lado, os geralmente pouco enfatizados aspectos institucionais que marcam o ius (seja ele ius naturale ou ius civile). Em seguida, analisaremos o uso de sociatus, correlacionando tal expressão com congregatus [hominum], e discutindo a tese da res publica como similar à figura contratual privada da societas (2.2.2).

expulsão dos reis tiranos); veja-se em Cic. Phil. 13.33.47 o apelo à libertas populi Romani ao lado da senatus auctoritas. No entanto, não funciona a libertas como conceito-chave da definitio: a libertas é importante como um dos elementos da constituição mista, ao lado da potestas (monárquica e, em seguida, das magistraturas) e da auctoritas (do Senado), não como elemento fulcral centralizador, inclusive por isso mesmo podendo se converter em libertate imoderata ac licentia (Pro Flacc. 16), termo que Cícero utiliza já em 59 a.C. ao defender o ex-pretor Lúcio Valério Flacco, quando explica o perigo de assembleias imoderadas. É polido e demasiado moderno o pudor de Schofield de compatibilizar Cícero com a democracia (nas entrelinhas do texto, a democracia liberal: um valor louvável neste século XXI, mas ausente em Cícero). O tratamento de Atkins é muito mais frágil, indo muito além do texto ciceroniano e interpretando o vocábulo res (de res publica) não apenas como propriedade, mas como "direito subjetivo" (para ele, ius = right) e passível de reclamação (é nesse sentido privatista que Atkins interpreta potestas e o uso do verbo recupero em Rep. 3.45). Citando fragmentos esparsos (e temporalmente desconexos) do Digesto, Atkins chega à conclusão - a nosso ver, sem reter mais as qualidades da explicação da "metáfora da propriedade" de seu orientador, Schofield - que "like the twenty-first-century reader of this book, Scipio and his interlocutors can talk about 'having rights'. The expression that Scipio uses is a common way to indicate a right in Roman Law. And as in Roman Law he introduces the language of rights into a matrix of ownership, freedom and power", cf. Atkins, Jed. W. Cicero on Politics and the Limits of Reason: The Republic and The Laws (Cambridge: Cambridge University Press, 2013), p. 136. Também Neal Wood extrapola a metáfora, interpretando que a res de res publica, como uma propriedade privada (moderna, esquece-se de dizer) é um tipo de trunfo absoluto erga omnes. São ambas leituras ligeiras e analógicas demais do que significavam res e libertas no ius civile romano (e partindo, também, de uma ênfase dramática na transposição entre "privado" e "público"). Wood, Neal. Cicero's Social \& Political Thought (Berkeley: University of California Press, 1988), p. 128-132. Conceber que há uma res que é de todos, e que esta res também engloba aspectos de propriedade - como de fato o encerra - é uma coisa, diversa de enxergar num romano a ideia de liberdade como um poder absoluto. Cícero não é Locke nem Dworkin: evidente nestes recentes tratamentos que o preço que se costuma aceitar para "modernizar" Cícero, ao gosto liberal, é o anacronismo. 
Iuris consensus e utilitatis communio: quid iuris?

Antes de mais nada, é útil lembrar que antes de escrever De Re Publica, em 56 a.C. já Cícero ensaiara em seu fundamental Pro Sestio - quando o tribuno da plebe, Públio Séstio, era acusado de vi, i.e., por ter se oposto com emprego de força (vis) ao bando armado de Clódio uma definição de res publica como res ad communem utilitatem ${ }^{44}$, uma res destinada e mobilizada para a utilidade comum. Cícero certamente tinha esse mesmo contexto em mente e optou por somar a expressão iuris consensus à utilitatis communio na definição de Rep. 1.39.

O primeiro dos dois elementos constituintes do populus é o iuris consensus. A expressão consensus e o verbo consentire não são nada incomuns na literatura latina nem em Cícero, evidentemente como o termo ius; no entanto, a formação iuris consensus aparece apenas em Rep. 1.39 e em Rep. 3.45, antecedida pelo possível sinônimo unum vinculum iuris em Rep. 3.43. Trata-se de um conceito técnico, consideremo-lo jusfilosófico ou técnico-jurídico. Existem duas questões imediatas para compreender o conceito e em ambos os casos estamos diante do terreno de discussão da melhor compreensão da pena ciceroniana: o que Cicero entendia por consensus e o emprego do genitivo iuris? Para ambas as questões a interpretação (e tradução) não pode ser tida como autoevidente. A respeito de consensus (bem entendido, entre aqueles que formam o populus, os cives) devemos nos perguntar efetivamente como ele se dá e qual o grau de participação dos cidadãos: há uma simples aderência coletiva à determinado ius (visão passiva: "aprovação", "assentimento" a fatos, sejam eles naturais ou humanos) ou um elemento de engajamento ativo na formação de consensus (visão ativa, que emprega um elemento de vontade $\left.^{45}\right)$ ? Tradutores e intérpretes parecem oscilar entre basicamente dois polos para a interpretação do genitivo iuris: capitaneá-lo na ideia de justiça, adequação moral ou jusnaturalista ou apontar como chave de leitura o sentido de positivação das normas jurídicas. ${ }^{46}$

${ }^{44}$ Cic. Pro Sest. 91. Mesma ocasião em que Cícero também define civitates e urbes, além de uma sensível presença do tema do consensus omnium bonorum.

45 Os "-ismos" abstratos podem mais atrapalhar do que ajudar em certos casos. Poderíamos chamar a esta de perspectiva voluntarista, termo que preferimos deixar de lado pela ambiguidade gerada nas conotações filosóficas modernas, por exemplo em Descartes, e na raiz de certas teorias contratualistas modernas ou contemporâneas, quando a vontade é tida como elemento predominante, essencial ou mesmo único da formação do corpo político e em oposição, por exemplo, à visões comunitaristas ou cognitivistas. Aqui simplesmente queremos distinguir duas interpretações de consensus e consentire: (a) a primeira que enfatiza o sentido de aderência a algo; (b) a segunda, que enfatiza a participação coletiva no que é consentido. Em ambos os casos, no entanto, existe um elemento de vontade (aquele que adere precisa ser convencido) e de aderência (ao produto final da deliberação).

${ }^{46}$ Quanto à primeira possibilidade são exemplos: "consenso de justiça" (tradução na dissertação de Isadora Prévide Bernardo), "assentimento de direito" (no sentido de direito natural, na interpretação de Luiz Marcos Silva Filho) e "agreement on law" (= natural law, na tradução de James E. G. Zetzel). 
Tentemos primeiro entender o substantivo mais geral. Consensus - particípio substantivado do verbo consentio, consentire, formado a partir da junção da preposição cum ao verbo sentio, sentire - possui algo que o destaca de outras composições verbais e nominais de mesma natureza: a preposição carrega um valor lexical próprio bastante denso, aderindo-o ao verbo inicial e modificando o valor do composto final. Cum carrega consigo as ideias de companhia, reunião, de participação da multidão ${ }^{47}$, no mesmo sentido da formação de comitium (cum-ire) e contio (e conventio, cum-vire), as assembleias políticas do populus; o verbo sentio, por sua vez, traduz-se em um "sentir" como ideia de percepção com alguns dos sentidos (inclusive os sentidos psicológicos e intelectivos). A ligação com o verbo sentire não tem meramente valor filológico, vez que sentire e sententia são as expressões que marcam a linguagem política e institucional do Senado $^{48}$; sentire-cum ou consentire exprimem um tipo de compartilhamento coletivo ${ }^{49}$ e, nos tempos da República, de forte conotação política e mesmo técnico-jurídica. ${ }^{50}$ Já a forma substantivada parece surgir realmente apenas no século I a.C. na

Quanto à segunda possibilidade: "common agrément on law" (= ius civile, na interpretação de Elizabeth Asmis); "consenso jurídico" (Francisco de Oliveira); "l'ordinamento medesimo" (Orestano).

${ }^{47} \mathrm{Um}$ atestado epigráfico normalmente referenciado nos trabalhos sobre consensus é justamente CIL. $\mathrm{I}^{2}$ 9 [=ILLRP. I 310], o epitáfio de Lúcio Cornélio Cipião (cônsul em 259, filho de L. C. Cipião Barbato): "L. Cornelio(s) L. f. Scipio / aidiles, cosol, cesor. / Honc oino ploirume cosentiont R[omane] / duonoro optumo fuise viro, / Luciom Scipione. Filios Barbati / consol censor aidilis hic fued a[pud vos]. / Hec cepit Corsica Aleriaque urbe, / dedet Tempestatebus aide mereto[d]". Disponível em: < $\mathrm{http} / /$ ancientrome.ru/art/artworken/index.htm?id=559 >. São os romanos, coletivamente, que consentem $($ cosentiont $=$ consentiunt $)$ que seu cônsul e censor fora um optimo viro, merecedor de um epitáfio por seus méritos políticos. Ver Cascione, Cosimo. Consensus: problemi di origine, tutela processuale, prospettive sistematiche (Napoli: Editoriale Scientifica, 2003), p. 61-67.

${ }^{48}$ Lintott, Andrew. The Constitution of the Roman Republic (Oxford: Oxford University Press, 1999), p. 74-85. Em passagem a respeito do ius fetiale ainda nos tempos da monarquia, Lívio nos apresenta uma trindade verbal (1.32.11-14, esp. 12): censeo, consentio, concisco são os três atos que marcam a reunião romana senatorial - dos antigos patres - de declarar a guerra após a rogatio do rex Anco Márcio. $\mathrm{O}$ ato de valorar certo tema ou fato (censeo), o ato estrito da deliberação, votação, do concurso de vontades (consentio), o ato de declarar-se ciente a respeito de uma dada decisão (concisco).

${ }^{49}$ É o que notou Hellegouarc'h ao contrastar o verbo consentire com o verbo adsentire: enquanto este último parece exprimir a ideia de simples adesão às ideias, convicções ou sugestões de outrem (geralmente uma aderência pessoal ou individual, como o ouvinte que se convence pela argumentação de um orador ou a exposição de um filósofo), consentire tem um sentido construtivo, participativo, próprio do Forum ou da Ágora. Ver Hellegouarc'h, Joseph. Le Vocabulaire Latin des relations et des partis politiques sous la République (Paris: Les Belles Lettres, 1963), p. 123; Cascione, 2003, p. 49 (nt. 7), 51-52.

${ }^{50}$ Mancuso, Gaetano. "Potere e consenso nell'esperienza costituzionale romana" in AUPA [Annali del Seminario Giuridico della Università di Palermo], vol. 41, 1991, p. 211. 
pena de Varrão ${ }^{51}$ e de Cícero $^{52}$ e, neste último, seguindo a conotação política (e institucional) do verbo. O emprego do substantivo consensus, resguardados os riscos de anacronismos, dá-se geralmente no sentido político, especificamente, de uma manifestação (não oficializada) da vontade coletiva ou da vontade popular; tendo por objeto alguma deliberação que passa, esta sim, por certos ditames de formalidade ou institucionalização. ${ }^{53}$

Em Cícero, a menos que haja um qualificativo que o modifique, o sintagma consensus (mesmo sem o genitivo iuris), tal qual o verbo que está na raiz de sua nominalização, diz respeito então a um momento associativo, ligado à intenção do povo; mais, um reconhecimento não passivo de um certo ius comum que é dividido por todos os associados da res publica. $\mathrm{E}$ em Rep. 1.39, de partida consensus, tal qual utilitas, é mais ainda: é um elemento que caracteriza a estrutura essencial do populus, um dos núcleos da definitio. Lívio utilizaria tais termos para descrever a história romana; Cícero, antes dele, emprega-o como caracterizador(-estruturante) do que distingue o populus de outras agregações de homens. Como apontou Mancuso, nesta operação - que pode ser compreendida como juspublicística, no sentido que um romano entenderia o termo - Cícero coloca o populus como centro de imputação de decisões a respeito

${ }^{51}$ Cícero não utiliza o termo apenas em De Re Publica (tanto como verbo, quanto com substantivo, com e sem o genitivo iuris), em sentido político, mas também como uma forma de traduzir (e traduzirinterpretando) a expressão grega sympatheia-symphonia, vide Cic. de div. 2.34 (... Qua ex coniunctione naturae et quasi concentu atque consensu, quam $\sigma v \mu \pi \alpha ́ \theta \varepsilon ı \alpha v$ Graeci appellant...) e Cic. de nat. deor. 3.28, (... stque in ea iste quasi consensus, quam synpatheian Graeci vocant ...). Em Cícero, as expressões qualificadas consensus omnium gentium (ou totius mundi, nationum omnium) são empregados no sentido de um acordo partilhado por todo o mundo ou com a humanidade (não apenas com aquilo que é contingente de uma civitas).

${ }^{52}$ Cícero não utiliza o termo apenas em De Re Publica (tanto como verbo, quanto com substantivo, com e sem o genitivo iuris), em sentido político, mas também como uma forma de traduzir (e traduzirinterpretando) a expressão grega sympatheia-symphonia, vide Cic. de div. 2.34 (... Qua ex coniunctione naturae et quasi concentu atque consensu, quam $\sigma v \mu \pi \alpha ́ \theta \varepsilon ı \alpha v$ Graeci appellant...) e Cic. de nat. deor. 3.28, (... stque in ea iste quasi consensus, quam synpatheian Graeci vocant ...). Em Cícero, as expressões qualificadas consensus omnium gentium (ou totius mundi, nationum omnium) são empregados no sentido de um acordo partilhado por todo o mundo ou com a humanidade (não apenas com aquilo que é contingente de uma civitas).

${ }^{53}$ A ritualística se mantinha plena na República tardia e valia tanto para o Senado quanto para as comitia ou contiones. Pensemos na oração solene Cícero reputa ser seu dever como cônsul em 63 a.C. ao presidir os comitia centuriata (pro Mur. 1) e os procedimentos descritos para a validade das votações e deliberações (v.g. Leg. 3.11; Dom. 50). Tentar distinguir elementos "religiosos" e "seculares" nas variadas descrições institucionais parece uma tarefa vã (ainda que uma busca pelo ídolo das origens venha a nos levar, quase sempre, para o terreno do colegiado dos pontífices, áugures, feciais e vestais). Tratam-se de formas que garantem a validade do ato. Sã casos em que a forma, no entanto, está mais ligada à conformidade da constituição da deliberação com os mores, os instituta e o ius, (i.e. o procedimento é válido por conformar-se pela forma em si mesma - mesmo que apenas a nível retórico) do que à moderna associação de forma como garantia, como na célebre frase de Ihering, "a forma é a inimiga jurada do arbítrio, a irmã gêmea da liberdade" (onde há conexão direta, aí sim, entre forma e libertas). 
do que é comum; o que se combina à interpretação de Schofield a respeito do binômio utilitatisconsensus servir de critério de legitimidade (ou análise de legitimidade) ${ }^{54}$; ao que se deve somar ainda a certo aspecto universal ou racional (no sentido do lógos antigo) preservado na raiz de cum-sentire, i.e., que todos os membros do populus são capazes de se identificar como parte daquela comunhão de iuris consensus e utilitas communio.

${ }^{54}$ Mancuso, 1991, p. 212-214; Schofield, Malcolm. "Cicero's definition of res publica" in Powell, Jonathan G. F. (editor). Cicero the philosopher: twelve papers (Oxford: Clarendon Press, 1995), p. 6977. Para Schofield, utilitas-consensus servem para identificar um populus; ligá-lo a uma res sua, passível de reivindicação; na tese de que essa res é especificamente a libertas. Mesmo que esse último ponto não pareça o mais adequado, até então Schofield tem razão: Cícero preocupa-se (mais do que Platão ou Aristóteles) em incluir na sua definição de res publica critérios de legitimidade que possam ser utilizados (por qualquer político, não apenas por filósofos) para diagnosticar os problemas de uma civitas, sempre de acordo com a função última de conservar a res publica. Todavia, a preocupação de Cícero com um critério ou fonte de legitimação - que, de fato, o difere de Platão, de Aristóteles ou do Pórtico - nem por isso o torna um autor "protomoderno". A filosofia política moderna - pensada aqui de Hobbes em diante -, que de fato se centra na discussão a respeito da legitimação do poder político, tem como sua fonte o individuo, pensado em termos universais. Cícero dá muito mais peso aos indivíduos do que seus pares filosóficos gregos, isso é certo, mas não encontramos também no Arpinate a ênfase radical na relação dos indivíduos (entre si, em relação horizontal; com o poder político, em relação vertical) como em um Hobbes, Locke, Kant ou Stuart Mill. A "protomodernidade" de Cícero também diminui se vemos outra característica comum que compartilha com a filosofia política antiga em geral: ele não se preocupa em fundamentar a própria existência da sociedade enquanto tal. Cícero, como qualquer estoico, acadêmico ou peripatético, acharia muito estranhas questões como "existe aqui uma sociedade?" ou "há vantagem em viver em sociedade?", preocupações filosóficas que são marcas do pensamento político após o humanismo, o Renascimento e o nominalismo. De fato, Cícero não se preocupa em descrever as origens da sociedade como Aristóteles (com o objetivo último de justificá-la), mas parte da mesma pressuposição de que a sociedade e o poder político são dados, são fatos, existem por natureza. A justificação do poder político e da existência da sociedade para algo fora do homem é marca do pensamento político e filosófico pré-moderno, aliás, independentemente de balizas cronológicas: vale para a "natureza" de Cícero e Aristóteles, o Lógos natural do Pórtico, ou para a origem divina do poder político em autores como Robert Filmer (contemporâneo de Hobbes) e Jacques Bossuet (escrevendo quase às portas do século XVIII). 
O genitivo iuris traz mais desafios interpretativos ${ }^{55}$ e pode ser visto de basicamente duas maneiras diferentes neste sintagma: como um genitivo objetivo ou subjetivo. ${ }^{56}$ Como genitivo subjetivo, ius seria o sujeito de consensus, não o objeto: do ponto de vista lógico e gramatical o consensus seria antes uma forma ou modalidade de expressão do $i u s^{57}$, ou seja, o ius é o sujeito da ação expressa pelo substantivo consensus - discute-se, decide-se a respeito do direito.

55 Varvaro enumera algumas traduções italianas que expressam bem o desafio do iuris consensus: 'consentimento di legge' (Odescalchi, Garofalo, Marchesi); 'riconoscimento o rispetto di um diritto comune' (Giovannetti); 'comunanza delle leggi' (Morica); 'accordo nel diritto o sulla osservanza della giustizia' (Ferrero); 'ordinamento giuridico approvato da tutti' (Guarino), 'comune coscienza giuridica' (Costa); 'consenso giuridico' (Cerami). Ver VARVARO, 1998, p. 469-470, nt. 59. Em seu Die Stoa, Pohlenz traduziu o termo como 'Übereinstimmung im Rechtsempfinden'; Büchner traduz iuris consensus como "Einverständnis im Recht", acrescentando que se trata do sentido mais amplo de Recht, "gegenseitige Anerkennung von Recht und Gerechtigkeit", a respeito do "direito" (ius), mas também da "justiça" (iustitia). Símile, Kohns enxerga no genitivo iuris de iuris consensus algo que ao mesmo tempo equivale à justiça e ao ordenamento jurídico (Rechtsordnung). Por outro lado, Sprute prefere "Rechtsbewußtsein (...) sondern als ursprungliches Rechtsempfinden", privilegiando a leitura jusnaturalista. Ver Asmis, 2004, p. 582, nt. 46; Kohns, Hans Peter. "Consensus iuris - communio utilitatis (zu Cic. Rep. I 39)" in Gymnasium Heidelberg, vol 81, 1974, p. 488-493; Sprute, Jürgen. "Rechts- und Staatsphilosophie bei Cicero" in Phronesis, vol. 28, n. 2, 1983, p. 154; Büchner, K. "Die beste Verfassung" in Studio italiano Filologia Classica, vol. 26, 1952 apud Asmis, 2004, p. 582, nt. 46.

${ }^{56} \mathrm{O}$ genitivo latino é sincrético. Neste caso, a equivalência material no caso genitivo acompanhando ações substantivadas pode acarretar uma ambiguidade semântica relevante. O genitivo objetivo é propriamente complemento nominal, expressando algo ou alguém que recebe ou sofre os efeitos da ação substantivada, daí, como objeto. O genitivo subjetivo pode ser entendido como outra forma de adjunto adnominal, mas que reflete a prática (como sujeito) da ação substantivada. Um exemplo comum é metus hostium oferecido por Aulo Gélio (NA 9.12.13-22): ele pode ser analisado como objetivo (hostes metiunt - os inimigos é que são temidos, são objeto da ação substantivada metus, como ocorre em Lívio, 1.19.4) ou subjetivo (hostes timent - os inimigos temem, são eles que praticam a ação substantivada, como em Tác. Ann. 14.23.3). De fato, outros tipos de genitivo (partitivo, de posse, de especificação etc.) não parecem se adequar bem com iuris consensus e utilitatis communio. Vide Almeida, Napoleão Mendes de. Gramática Metódica da Língua Portuguesa (São Paulo: Saraiva, 2010), p. 423-424 (§ 677) e Bechara, Evanildo. Moderna Gramática Portuguesa (Rio de Janeiro: Nova Fronteira, 2009), p. 293 294, 453-454. Para Horrocks, Geoffrey. "Latin Syntax" in: Clackson, James (editor). A Companion to Latin Language (Hoboken: Wiley-Blackwell, 2011), p. 142, nt. 8, não seria disparatado afirmar que o genitivo subjetivo poderia representar apenas um uso evoluído do genitivo possessivo (que é adjunto) junto de ações substantivadas e que retém seu significado verbal original. Essa tese já está antecipada em Napoleão Mendes de Almeida ao tomar o genitivo subjetivo como forma de adjunto adnominal; contra Bechara, que a despeito da diferença semântica reconhece os dois casos como complementos nominais quando a ação substantivada tenha origem em verbo transitivo direto e a presença de sujeito (o que, data venia parece esvaziar a utilidade da análise de diferentes funções sintáticas para diferentes correspondentes semânticos).

${ }^{57} \mathrm{Na}$ bibliografia, o principal defensor desta posição é Filippo Cancelli, que parte da sintaxe do verbo. Segundo ele, consensus é particípio substantivado derivado do verbo consentio (consentire), verbo que exclui o objeto direto e se constrói de outros modos, geralmente por meio de preposição ( cum, de, in, inter, ad) mais ablativo, dativo ou acusativo. Isso corresponderia a um aspecto estático do verbo consentire que resvalaria no substantivo consensus: se o verbo precisa de outras palavras para expressar seu objeto, só poderia se tratar de genitivo subjetivo, não objetivo. Cf. Cancelli, Filippo. "'Iuris consensu' nella definizione ciceroniana di 'Respublica'" in Rivista di Cultura Classica e Medioevale, vol. 4, 1972, p. 256 ss. 
Como genitivo objetivo o iuris consensus passa a representar, como seu objeto, uma concreta comunhão que reflete o que é o ius; o genitivo objetivo expressaria tão somente que ius seria o objeto da ação (um cum-sentire ou consensus que se dá sobre o direito). O genitivo subjetivo é acolhido quando a interpretação de iuris consensus em Rep. 1.39 quer enfatizar a ideia de consonância, harmonia ${ }^{58} \mathrm{e}$, ademais, uma ligação com a concordia ordines de Cícero, especialmente a analogia da harmonia musical do fim do segundo livro (Rep. 2.69). Já o genitivo objetivo é mais privilegiado nas interpretações que leem diferentemente os termos de Cícero, especialmente societas iuris (Rep. 6.13; Leg. 1.35) e aequabilitas (Rep. 1.69) ${ }^{59}$, e também pode servir melhor ao aspecto pró-volitiva que aproxima res publica de uma societas.

Uma pista para a interpretação do tão particular sintagma iuris consensus pode ser o paralelismo estilístico que Cícero busca no emprego da expressão utilitatis communio, igualmente formada por genitivo e ablativo. Concordamos com Varvaro no sentido de que tais expressões são simétricas, devendo ser ambas interpretadas em sua associação mútua e também com o particípio sociatus que se segue. ${ }^{60}$ Seria difícil encaixar este utilitatis como um genitivo subjetivo: trata-se, muito mais adequadamente, de um genitivo objetivo (ou um genitivo atributivo, mas o paralelismo reforçaria o genitivo objetivo). Não tomemos, no entanto, este esquema gramatical com uma bipartição semântica absoluta nas questões de filosofia do direito (como se estivéssemos diante de um embate no qual genitivo subjetivo necessariamente representasse o aspecto volitivo contra genitivo objetivo no aspecto jusnaturalista ${ }^{61}$ ). Como se

${ }^{58}$ Não à toa, aparece sobretudo nas interpretações estoicizantes de Cícero.

${ }^{59}$ É o que pensa Anselmo: para a autora, claramente coetus multitudinis é o sujeito da oração, e ius, de iuris consensus, um objeto de consensus, vide Anselmo, Giuseppina Aricò. "Ius publicum-ius privatum in Ulpiano, Gaio e Cicerone" in AUPA [Annali del Seminario Giuridico della Università di Palermo], vol. 37, 1983, p. 618-627. Esta tese é acolhida por Varvaro, cf. Varvaro, Mario. "Iuris consensus e societas in Cicerone: un'analisi di Cic., de rep., I, 25, 39" in AUPA [Annali del Seminario Giuridico della Università di Palermo], vol. 54, n. 1, 1998), p. 469-475; e também é acolhida, de modo próprio, por Asmis (2004, p. 579-581).

${ }^{60}$ Parece ser um pouco apressado afirmar como Varvaro (2003, p. 460-466) a paridade semântica de consensus com communio, a despeito da aparição da expressão iuris communio (Rep. 2.48), e reciprocamente a legis communio (Leg. 1.23). Este fragmento parece remeter realmente ao significado de direito natural (reforçado, na mesma oração, pela expressão humanitatis societas) e tão somente a ele; em Rep. 1.39 ele parece querer dizer algo a mais, o que seria uma boa razão para Cícero forçar o paralelismo em tal construção. Feito este arremedo nossas conclusões são similares: tudo indica uma comunhão ou coparticipação (no sentido ativo de associação).

${ }^{61}$ O exemplo de Anselmo (1983, p. 620-622, nt. 25) é importante para demonstrar, no entanto, que é defender a interpretação de um genitivo objetivo em iuris consensus sem uma ênfase voluntarista, mas também sem uma ideia de assentimento ao direito excessivamente estoica. Assim que Anselmo pode qualificar iuris consensus como em uma comunhão que se concretiza em uma atitude interior (um cumsentire) a respeito do ius. 
sabe, somente o contexto poderá resolver a ambiguidade que advém do sincretismo sintático e indicar se se trata de um genitivo subjetivo ou objetivo. ${ }^{62}$

Precisamos então que a semântica venha a nosso socorro perante a curiosa construção ciceroniana. Lembremos que estamos em uma definitio, e uma que não é dada meramente como exemplo (como Cícero faz em outras ocasiões no De Inuentione e Topica) ${ }^{63}$, mas como base firme de toda a discussão. Cícero parece ter querido dizer duas coisas sem redundância: o populus o é enquanto tal quando associado (sociatus) pela presença simultânea (et) daqueles dois elementos; correspondem em importância, mas não um ao outro (como para Varvaro).

Para isso é necessário voltar à comparação com o contemporâneo texto Pro Sestio. ${ }^{64} \mathrm{Na}$ ocasião, tanto quanto ao longo dos dois primeiros livros De Re Publica, Cícero está fazendo um contraste claro entre dois estágios da vida humana em sociedade: o ius (de iuris consensus) é precisamente aquilo que marca a fase humana em uma civitas (e, na melhor forma, res publica), distinguindo-a do seu oposto: vis, a violência, desconhecimento e não efetividade do direito (seja ele natural, seja ele ius civitatis). O contraste entre ius e vis é uma chave de leitura importante para compreender globalmente a função do direito em Cícero, seja ele natural, seja ele ius civitatis ou ius civile. É por causa da violência desmedida de verdadeiros inimigos da res publica como Clódio, justificou Cícero na ocasião, que seu cliente teria sido forçado a usar ele mesmo violência para se defender. De fato, da maneira como coloca as duas alternativas direito vs. não-direito, Séstio e Clódio -, somos levados a concordar com Cícero que os dois não podem estar corretos ao mesmo tempo e que um dos dois se utilizou da violência em forma contrária a todo o ius. Exatamente dez anos antes de Pro Sestio, em Pro Cluentio o jovem orador Cícero já havia tentado persuadir os juízes do caso que as leges eram a fons aequitatis, o fundamentatum libertatis, residindo na alma, na mente da civitas, mas também em seu consilium e em sua sententia (Pro Clu. 146).

Muito do que Cícero tinha por dizer a esse respeito - o contraste ius e vis - já fora expresso na oração Pro Caecina de 69 a.C., considerado pelo próprio Cícero seu mais importante discurso em casos privados. ${ }^{65} \mathrm{Na}$ ocasião Cícero explorou cabalmente a dicotomia

${ }^{62}$ Faria, Ernesto. Gramática Superior da Língua Latina (Rio de Janeiro: Livraria Acadêmica, 1958), p. 344; Jones, Peter V.; Sidwell, Keith. Aprendendo latim (São Paulo: Odysseus, 2012), p. 586.

${ }^{63}$ Cic. Top. 9 e Top. 28 apresentam duas definições de ius civile: a primeira para ilustrar propriamente a função de uma definitio e, na segunda, da partitio e da divisio. Em De inv.2.65-69 Cícero define o ius naturae em seus elementos. Nessas passagens, no entanto, interessa a Cícero menos o definiendum do que a de criar para seu leitor uma ilustração dos diversos modos de ordenação do discurso.

${ }^{64}$ Cic. Pro Sest. 29, 91-92.

${ }^{65}$ Cic. Orat. 102. 
entre ius e vis, entre o direito e a violência não autorizada, essa uis que é oposta ao direito (Caec. 5: vis ea quae iuri maxime est adversaria); pois nada é mais inimiga do direito do que esse tipo de violência (Caec. 33, nec iuri quicquam tam inimicum quam vis). E, contudo, é um tipo específico de direito que combate a vis: o ius civile. A "eulogia do ius civile" (Caec. 65-75, especialmente 74-75) revela que o ius civile, isto é, o ius civitatis deriva da utilitatis communio, é aquilo que existe para preservar a comunhão (Caec. 70; 49-50). ${ }^{66} \mathrm{O}$ manancial de instituições e de normas jurídicas humanas - venham elas de onde vierem: dos costumes, das leis comiciais, do Senado - do ius civile existem para impedir que a disputa de poder individual extrapole os limites da vida comum (Caec. 71-73). ${ }^{67}$ Poderíamos brincar com os termos: o ius civile que discute Cícero - geralmente entendido como "direito privado" por romanistas e historiadores sem maiores ressalvas - tem uma função pública, que vai do nível do civis para o da civitas. Diferentemente dos homens, o ius (agora no sentido humano: ius civile, ius honorarium) - que

${ }^{66}$ Cic. Caec. 70: "Nam qui ius civile contemnendum putat, is vincula revellit non modo iudiciorum sed etiam utilitatis vitaeque communis; qui autem interpretes iuris vituperat, si imperitos iuris esse dicit, de hominibus, non de iure civili detrahit; sin peritis non putat esse obtemperandum, non homines laedit, sed leges ac iura labefactat; quod vobis venire in mentem profecto necesse est, nihil esse in civitate tam diligenter quam ius civile retinendum. Etenim hoc sublato nihil est qua re exploratum cuiquam possit esse quid suum aut quid alienum sit, nihil est quod aequabile inter omnis atque unum omnibus esse possit.”. Cic. Caec. 49-50: “... Opinor. Ain tu? qui tam diligenter et tam callide verbis controversias non aequitate diiudicas, et iura non utilitate communi sed litteris exprimis, poterisne dicere deiectum esse eum qui tactus non erit? Quid? detrusum dicesne? nam eo verbo antea praetores in hoc interdicto uti solebant (...) rem et causam et utilitatem communem non relinquere solum sed etiam prodere?".

${ }^{67}$ Ao contrário das mais famosas orações de Cícero, geralmente envolvendo julgamentos de delitos, Pro Caecina é essencialmente uma querela privada. Seu cliente, Aulo Caecina, disputa com Sexto Ebúcio a posse de uma fazenda que teria herdado de sua falecida esposa, Cesênia. Caecina, ao tentar tomar posse da fazenda, fora repelido por um bando armado por Sexto Ebúcio (que, também herdeiro, recebera menos de dois por cento do patrimônio da de cujus). Caecina mobiliza o pretor urbano e alça um julgamento na corte de recuperatores pleiteando ter sido alvo de violência injusta (e, daí o interdito pretoriano de vi armata ser sua base legal). A discussão jurídica é bastante técnica e diz respeito à aplicabilidade do interdito, por conta do específico verbo deiectio ao caso de Caecina. Habilmente, Cícero esquematiza a dicotomia entre ius e vis e a transporta para os dois querelantes. Caecina é o cidadão que está simplesmente invocando aquilo que lhe é de direito pelo ius Romanorum, alguém que se servira do interdito possessório diante da necessidade e Ebúcio é, por sua vez, a criatura da audácia, impudentia e petulantia; Caecina é apoiado pela vox iuris enquanto Ebúcio é apoiado apenas pela vox libidinis (Caec. 76-77), importando ser este último, no fundo, alguém contrário ao ius, a aequitas, à ordem social prezada pelos romanos (Caec. 33). Uma apreciação completa do Pro Caecina é precisamente o objeto do já clássico livro de Bruce Frier, The Rise of the Roman Jurists (1995). Em que pesem nossas ressalvas quanto a tese da "instabilidade do direito" nos tempos de Cícero - resultado, atesta o próprio Frier, de sua leitura partir dos conceitos de "segurança jurídica", anseio por "estabilidade" e pela "tendência liberal" (sic) dos juristas da República tardia -, a análise a respeito do argumentum ciceroniano sobre o ius civile em Caec. 65-75 é valioso. Veja-se ainda Harries, Jill Diana. "Cicero and the Definition of the Ius Civile" in Clark, Gillian; Rajak, Tessa (eds.). Philosophy and Power In the Graeco-Roman World: Essays in Honour of Miriam Griffin (Oxford: Oxford University Press, 2002); e especialmente cf. Harries, Jill Diana. Cicero and the Jurists: From Citizens' Law to the Lawful State (London: Duckworth, 2006), p. 185-203. 
é resultado de maturação histórica e temporal, de instituições, costumes e leis - seria imune a influência, poder e riqueza, e garantiria os direitos "de propriedade" (pensa Cícero em todas as questões envolvendo obligationes, em posse, propriedade, sucessões, direitos de vizinhança etc.), devendo ser assim respeitado e protegido em todos os tempos.

Uma objeção que imediatamente se projeta: onde estaria, então, o jusnaturalismo de Cícero? Seria ele um apologeta de um protocontratualismo ou de um protopositivismo jurídico latu sensu mais apropriado a um sofista como Trasímaco? Afinal, não é o próprio Cícero que, no terceiro livro do De Re Publica, inverte a ordem histórica do discurso de Carnéades (terminando não com o discurso contra, mas com o discurso a favor da iustitia), o mesmo Cícero que escreve o De Legibus (que possui acepções muito mais universalistas do que aquelas em De Re Publica), que cuida de definir ius naturale e vera Lex? ${ }^{68}$ A confusão se dá por duas razões: a primeira, pelo excessivo esquematismo que opõe o ius naturale ao ius positivum, muito $^{69}$ mais forte nos intérpretes contemporâneos do que em Cícero ou, ademais, no direito romano; a segunda, por desconsiderar as peculiaridades do jusnaturalismo ciceroniano, simplesmente rotulando-o como platônico ou estoico.

É claro que Cícero parte da concepção de direito natural e, ademais, de uma iustitia, que a política não se trata simplesmente de pacto (como o próprio Filo não acredita mesmo ao emular Carnéades em Rep. 3.23). O ius civitatis e, na realidade, todos os atos humanos, podem ser julgados pelo modo como obedecem aos officia, conformam-se à iustitia e à vera Lex (Rep. 3.33). E, no entanto, mesmo que se queira ler Cícero como um estoico, o Arpinate não é Zenão ou Crisipo. Cícero prestou atenção ao argumento estoico de que a agremiação dos homens se dá por natureza (para o Pórtico partindo da ratio, do Logos), e que as civitates se formam por conta disto (Rep. 1.39). Todavia, Cícero não se satisfaz em discutir apenas a ação do homem sábio (o sapiens estoico, aquele que pode alcançar a virtude na sua absoluta integralidade: um ideal inalcançável até mesmo aos fundadores da Stoá). A ratio do homem comum, daquele que vive no mundo histórico, está justamente no processo de escolha e seleção dos chamados bens indiferentes - o efetivo reino da criação humana, da cultura, da política e do direito. Com isso bem entendido, não parece um contrassenso que homens como Cipião ou Lélio advoguem a

${ }^{68}$ V.g. Cic. Rep. 3.33; De Nat. Deor. 2.22; De Leg. 1.14.

${ }^{69}$ Forschner, Benedikt. "Law's Nature: Philosophy as a Legal Argument in Cicero's Writings" in Du Plessis, Paul J. (ed.). Cicero's Law: Rethinking Roman Law of the Late Republic (Edinburgh: Edinburgh University Press, 2017), p. 51-52. Como destaca a autora, não é que Cícero não distinguisse entre direito natural e direito positivo (o livro terceiro do De Re Publica bastaria para tal), mas que isso não explica a relação dessas formas de iura em Cícero (ou, ademais: ius naturae, ius civile, ius gentium, para citar apenas as partições mais comuns que aparecem em jurisconsultos como Gaio e Ulpiano). 
vida ativa pública na urbs sem abrir mão da doctrina: a vida política é a gerência da res publica, res populi, e de todas as coisas humanas a ela inerentes. Assim como Cícero não está interessado em longos debates a respeito de um "estado ideal"70 - sua res publica é uma civitas bem histórica e concreta -, ele não está interessado em debater unicamente o ius naturale, sabendo que este, perfeito que seja - e presente no interior do homem como naturalis ratio -, não é aquele que efetivamente opera no mundo dos homens. Ele é sentido: é a naturalis ratio que congrega os homens por natureza.

Como já citado, em Rep. 2.69-70, Cipião se serve da imagem da harmonia musical para - ao estilo platônico - conectar consensus com justiça e, pela analogia, com concentus (harmonia ou concórdia de vozes, do verbo concino) entre os três ordines. Assim como diferentes instrumentos e musicistas precisam se coordenar para produzir um som balanceado, harmônico, diferentes pessoas - de ordens mais baixas e mais altas - precisam contribuir para a concórdia da res publica, aquilo que garante sua estabilidade e salvação; igualmente, o que garante e mantém sua iustitia. Apesar de extremamente fragmentado, o livro três - que retém a grande discussão sobre a iustitia - precisa ser pensado aqui precisamente nesses termos: não uma discussão abstrata sobre a justiça, mas sobre um momento de conformação e de especificação entre o direito natural (que é sentido por todos enquanto homens) e o direito humano (que é produzido pelos homens, como resultado natural desta participação do direito; mas que, justamente por ser um produto cultural e humano, é diverso e, potencialmente, menos perfeito).

${ }^{70}$ Como escreveu Zetzel para outras funções: "Cicero and Virgil are concerned not simply with ideal states; it is the historical reality of the Roman state that preoccupies them. Natural law may work in the cosmos, and it may serve as an ideal to which humans may aspire; but in Rome it conflicts with a different law: the historical realities of error and ignorance, violence and decline. That natural law, the law of human limitations, is one of which Cicero and Virgil are painfully aware. Both De Republica and the Aeneid acknowledge-however unwillingly-the resistance of history and of time to Rome's potential for justice and for eternity, the Carneadean debate that can never be settled between the laws of nature and the natural law", cf. Zetzel, James E. G. "Natural Law and Poetic Justice: a Carnedean in Cicero and Virgil" in Classical Philology, vol. 91, n. 4, 1996, p. 318. Em mesmo sentido Powell, 2001, p. 2032, que atesta, ademais o tratamento exemplar (e não, ideal) da história de Roma no livro segundo (contra: Cornell, T. J. "Cicero on the Origins of Rome" in Powell, Jonathan G. F.; North, J. A. Cicero's Republic: Bulletin of the Institute of Classical Studies, Supplement n. 76, 2001, p. 41 ss). A questão da "idealidade" da res publica, parece-nos, relativamente desaparece uma vez que os lugares-comuns de leitura são expurgados. Cícero não utiliza ideal (ou eidos) em lugar algum ao sei referir à res publica. Em Rep. 1.45 Cícero fala moderatum et permixtum tribus; em Rep. 1.69 Cícero se refere a aequabilitas e a firmitudo. O primeiro tem claro sentido de constância, regularidade (cf. Cic. De Off. 1.90) ou, sentido figurado, como conservação (De Or. 1.188). Menos crível - na verdade, contra textual - ainda interpretar simultaneamente que Cícero fala de uma optimo status civitatis (ou res publica) eterna, guiada pelo direito natural (como em Silva Filho, Luiz Marcos da. "A conjunção et na definição ciceroniana de populus" in Cadernos de Filosofia Alemã, n. 21, 2013, p. 86-92). 
Cipião pede licença a certa altura, em Rep. $3.43^{71}$, para afirmar que as três formas "degeneradas" - o domínio de um, de alguns ou da multidão - não são formas de uma res publica - não há populus - por carecerem de (1) consensus, por não haver (2) societas coetus nem tampouco (3) unum vinculum iuris. Cícero exige aqui as duas coisas: o respeito ao ius civitatis, fruto do iuris consensus e do ajuntamento de homens, que preserva (como demonstrou em Pro Caecina) a utilitatis communio; ao mesmo tempo, Cícero também destaca o papel do direito natural como elemento catalisador a ser levado em conta na criação normativa, na legitimação das mesmas - uma vez que não pode haver verdadeira communio contrária à justiça, ao que comumente se sente como justo. Afinal, se o direito natural é a origem da união entre os homens, o direito da cidade é o fruto que não deve cair tão longe do pé de árvore. ${ }^{72}$ Cícero consegue um amálgama entre natura, lex e ius que neutraliza a dicotomia ou, pelo menos, não comporta uma dicotomia tão forte e absoluta entre physis e thesis-nomos. ${ }^{73}$

É exatamente neste ponto que podemos começar a distinguir - mas, não separar - em Cícero os componentes "institucional" e "moralizante" da res publica, ambos presentes e importantes. O respeito às instituições, ao ius - civile, honorarium, religioso, público, humano - é o garantidor de que a união primeira dos homens, motivada por razões naturais, permaneça sempre viva e funcional. Uma vez que, pensava Cícero, os romanos já haviam alcançado o optimus status civitatis, restava, além de salvaguardar tais instituições - reformando-as aqui e acolá onde forem necessárias, sem grandes saltos institucionais, como aqueles de Sila, de César ou dos períodos de triunvirato - centrar as atenções no elemento humano: os "operadores" da

${ }^{71}$ Cic. Rep. 3.43. “**'reportare. ergo illam rem populi, id est rem publicam, quis diceret tum dum crudelitate unius oppressi essent universi, neque esset unum vinculum iuris nec consensus ac societas coetus, quod est populus? atque hoc idem Syracusis. urbs illa praeclara, quam ait Timaeus Graecarum maxumam, omnium autem esse pulcherrimam, arx visenda, portus usque in sinus oppidi et ad urbis crepidines infusi, viae latae, porticus, templa, muri nihilo magis efficiebant, Dionysio tenente ut esset illa res publica; nihil enim populi, et unius erat populus ipse. ergo ubi tyrannus est, ibi non vitiosam, ut heri dicebam, sed, ut nunc ratio cogit, dicendum est plane nullam esse rem publicam".

${ }^{72}$ Por isso, Varvaro ao mesmo tempo tem e não tem razão neste ponto. Com ele, concordamos que unum vinculum iuris não diz respeito ao direito positivo (uma lex rogata) ou àquilo que chamamos hoje de lex publica; e que, combinando Rep. 3.33 e Leg. 1.28, (neque opinione sed natura constitutum esse ius), percebemos o papel da lex naturae no ordenamento jurídico em Cícero, que não é um moderno constitucionalista ou um positivista jurídico. Nesse sentido, Cícero é, sim, "anticontratualista" (seja na modalidade sofista, seja na modalidade liberal moderna) e jusnautralista. Isso não exclui absolutamente, no entanto, o elemento voluntarista - ou o elemento 'societário' - que se une ao elemento natural e gregário. O primeiro instinto de agregação é necessário, mas não suficiente, para uma res publica, que não existe sem os aspectos institucionais.

${ }^{73}$ Forschner, 2017, p. 55. 
res publica (o civis ideal dos dois últimos livros perdidos ${ }^{74}$ ), com a formação intelectual e moral $^{75}$, aqueles responsáveis por manter a concórdia. ${ }^{76}$

Temos fragmentos textuais nesse sentido. O mais claro deles encontra-se relativamente íntegro no começo do quinto livro (Rep. 5.1 na edição de Ziegler ${ }^{77}$; preservado, contudo, por Agostinho). Diante de um verso paradigmático de Ênio (moribus antiquis res stat Romana virisque), Cícero equivale a excelência dos homens que guiam a res publica (i.e. aqueles que devem ser os conhecedores da justiça, Rep. 5.5) à excelência dos mores republicanos. Em uma bi-implicação, o direito, as instituições e os costumes auxiliam a gerar bons cidadãos, os mesmos que são necessários para mantê-los ou aperfeiçoá-los.

Outra passagem surge no momento em que Cícero oferece uma segunda explicação para a origem da vida comum: o desejo de uma civium beate et honeste vivendi societas (Rep. 4.3); esta vida feliz e honesta depende de um moderator rei publicae (aquele que modera, rege, tempera, "opera" as instituições da res publica) para manter a vida de seus cidadãos permeada

${ }^{74}$ Despiciendo lembrar que, no mundo antigo, a cidadania e a vida política não é para todos. Mesmo no contexto de poucas décadas seguindo-se às guerras sociais (91-88 a.C.) e à extensão da cidadania para a maior parte dos povos da Península Itálica, Cícero parte de uma Roma abarrotada de escravos, peregrini, e de cidadãos romanos cujo status não inclui prerrogativas políticas (mulheres, impúberes, loucos etc.). Outrossim, considerando o papel da educação na formação do cidadão - seja no modelo platônico, seja no ciceroniano; perdemos estes livros do De Re Publica, mas De Oratore e Topica nos dão alguma ideia da educação em Cícero - e dos níveis de societas em Cícero (que incluem a família), a res publica permanece operacional em seu objetivo de conservação pela adequada participação ode todos nessa ordem. Parece esse ser o aspecto mais esquecido pelos republicanos neorromanos ao lerem apressadamente os antigos, especialmente romanos como Lívio ou Cícero. As prerrogativas políticas e individuais do republicanismo ciceroniano possuem pouco em comum com as aspirações modernas e se destinam a preservar uma ordem de coisas bem específica.

${ }^{75}$ Com diferenças de ênfases seguimos aqui Powell, 2001, p. 26-27.

${ }^{76}$ Cascione, 2003, p. 70-78.

${ }^{77}$ Cic. Rep. 5.1 (= Agost. De Civ. Dei 2.21). "Quando ergo res publica Romana talis erat, qualem illam describit Sallustius, non iam pessima ac flagitiosissima, sicut ipse ait, sed omnino nulla erat secundum istam rationem, quam disputatio de re publica inter magnos eius tum principes habita patefecit. Sicut etiam ipse Tullius non Scipionis nec cuiusquam alterius, sed suo sermone loquens in principio quinti libri commemorato prius Enni poetae uersu, quo dixerat: 'Moribus antiquis res stat Romana uirisque'. Quem quidem ille uersum, inquit, uel breuitate uel ueritate tamquam ex o raculo quodam mihi esse effatus uidetur. Nam neque uiri, nisi ita morata ciuitas fuisset, neque mores, nisi hi uiri praefuissent, aut fundare aut tam diu tenere potuissent tantam et tam uaste lateque imperantem rem publicam. Itaque ante nostram memoriam et mos ipse patrius praestantes uiros adhibebat, et ueterem morem ac maiorum instituta retinebant excellentes uiri. Nostra uero aetas cum rem publicam sicut picturam accepisset egregiam, sed euanescentem uetustate, non modo eam coloribus isdem quibus fuerat renouare neglexit, sed ne id quidem curauit, ut formam saltem eius et extrema tamquam liniamenta seruaret. Quid enim manet ex antiquis moribus, quibus ille dixit rem stare Romanam, quos ita obliuione obsoletos uidemus, ut non modo non colantur, sed iam ignorentur? Nam de uiris quid dicam? Mores enim ipsi interierunt uirorum penuria, cuius tanti mali non modo reddenda ratio nobis, sed etiam tamquam reis capitis quodam modo dicenda causa est. Nostris enim uitiis, non casu aliquo, rem publicam uerbo retinemus, re ipsa uero iam pridem amisimus". 
de glórias, propriedades, glórias e uma virtude honesta. ${ }^{78}$ Tal vida é garantida pelas leis e pelas instituições (aspecto institucional); mas a mantença mais duradoura possível se dá por meio da educação dos cidadãos ou, em última instância, daqueles que guiarão a vida política dali em diante (eis nesse sentido preciso o papel do indivíduo e da moral individual em Cícero, bem como a função do conhecimento do direito natural.

E fica assim esclarecido também o significado mais profundo da utilitatis communio é a comunhão ou divisão daquilo que é útil (não os verdadeiros beneficia que levam à virtude, mas os bens moralmente "indiferentes" - e que são, de fato, os que operamos no mundo dos homens), tanto do ponto de vista material (com a enorme gama de prerrogativas proprietárias e sucessórias específicas do ius civile, por exemplo) quanto anímico. Esta communio é a função realizada pelo consensus: a participação comum no direito (o direito natural de todos os homens, e também o direito que concidadãos dividem na civitas, quando a "vontade" e a "criação" filtram e especificam o direito natural) e a comunhão de benefícios estão numa relação única. Afinal, quod est civitas nisi iuris societas (Rep. 1.49)? ${ }^{79}$

Ao iuris consensus - na totalidade e na complexidade com a qual os romanos, inclusive Cícero, pensavam seu ordenamento jurídico ${ }^{80}$, o ius entre o direito natural e o direito humano recebe dentro da definitio a incumbência de representar a condição para que o populus (sociatus) possam efetivamente beneficiar a todos (a utilitatis communio). Ao mesmo tempo, se o ius é uma parte essencial da definição, esta exige um comportamento condizente com as normas que governam a civitas: o direito é a "corrente" que une as pessoas em societas em uma res publica, sob um império das instituições que não está afastado da ideia de natureza. ${ }^{81}$

\footnotetext{
${ }^{78}$ Veja-se ainda Att. 8.11.1, que contém um pequeno trecho perdido do livro quinto (= Rep. 5.8a). "'Vt enim gubernatori cursus secundus, medico salus, imperatori victoria, sic huic moderatori rei publicae beata civium vita proposita est, ut opibus firma, copiis locuples, gloria ampla, virtute honesta sit. huius enim operis maximi inter homines atque optimi illum esse perfectorem volo". Os fragmentos Rep. 1.fr.1a-b de Nônio parecem compatíveis com essa análise.

${ }^{79}$ Que aparece melhor explicitada somente mais tarde, quando Cícero afirma "Hi sibi nihil iuris, nullam societatem communis utiliatem causa statuunt esse cum civibus" (Cic. De Off. 3.28).

${ }^{80}$ Orestano, Riccardo. Il problema delle persone giuridiche' in diritto romano (Torino: G. Giappichelli, 1968), p. 111-114 e nt. 23, se presta a esta síntese. Res publica, res populi, como coetus multitudinis iuris consensu et utilitatis communione sociatus ao mesmo tempo constitui e é o ordenamento jurídico, no aspecto concreto, material, no reflexo de uma situação objetiva de convivência. O que, como já salientarmos, não significa uma visão positivista do direito.

${ }^{81}$ Parece ser neste tom ciceroniano a definição de ius civile que principia o Digesto com Ulpiano (Ulp. 1 inst., d.1.1.6pr., ius civile est, quod neque in totum a naturali vel gentium recedit nec per omnia ei servit: itaque cum aliquid addimus vel detrahimus iuri communi, ius proprium, id est civile efficimus). Tal recepção de ideias, no entanto, requereria uma apreciação mais totalizante dos fragmentos de Ulpiano para ser compreendida.
} 
Sociatus e congregatus - a res publica é uma societas?

As conclusões a respeito desses termos já estão implicadas na argumentação acima, cabendo-nos apenas colocá-las à luz.

A última oração de Rep. 1.39 - independente do complemento de Nônio, que a reforça com cores estoicas - complementa a definição de populus: este ajuntamento dos homens (hominum coetus... congregatus) que leva à formação de um populus se dá por natureza (natura), não pela fraqueza (é nesse sentido que Cícero emprega inbecilitas) dos homens singulares. Se em Rep. 1.38 Cícero se distancia do tratamento dos gregos a respeito do tema, nesta última oração de Rep. 1.39 as ressalvas são para com a tese respeito da prima causa coeundi das comunidades como a fraqueza de seus indivíduos. ${ }^{82}$ A transformação de um grupo de homens num populus altera toda a equação. O consensus iuris e a utilitatis communio são aqueles elementos que permitem que uma congregatio forme um populus; mas, há uma etapa subsequente, a de formação da civitas particular (seja ela um regnum, civitas optimatium ou civitas popularis - cada um dotado de sua especificidade, consilium quoddam, Rep. 1.42). A passagem se dá desta forma: é por natureza que os homens se agregam, espontaneamente; mas, o fator que inspira a formação posterior da civitas é a conservação - uma palavra muito mais romana do que a liberal "proteção" - da propriedade, dos bens e dos stati jurídicos. Uma res publica, como civitas, requer logicamente que seu populus crie suas próprias leges, regule-se por meio das magistraturas e da religião, os três principais tópicos da obra De Legibus.

A expressão sociatus fica mais clara se levamos em conta um texto mais tardio a respeito das formas de associação ou sociedade (De Off. $1.53 ; 3.39$ ). Nele, Cícero diferencia quatro graus de societates em ordem crescente: a familia, a civitas, a gens, e o grau mais amplo (latisime), uma societas entre todos os homens. É uma apropriação ciceroniana dos círculos sociais dos estoicos: os graus de societates levam a um processo de especificação desde um significado mais amplo até um mais estreito. Igualmente, o ius naturale e o ius gentium atuam sobre os graus mais amplos: o ius civile, as leges e os mores específicos de cada povo (o ius proprium civitatis do jurisconsulto Gaio) incidem nessa cadeia de especificação. Não há exclusão: os homens possuem os direitos da natureza, partilham com todos os povos o ius gentium, e respondem ainda pela produção normativa de seu populus em uma civitas específica.

${ }^{82}$ A tese da inbecilitas é a tese que, como lembra Filo (Rep. 3.23) ao parafrasear antiga definição platônica, afirma iustitiae non natura nec voluntas, sed imbecilitas mater est (Plat. Rep., 369b; Protag. 322b-d). Parece coadunar-se com a descrição epicurista de Lucrécio (Lucr. de rerum nat. 5, vv. 10191147). 
A congregação dos homens se dá por natureza, e a sua especificação na vida em comum descrita por Cícero, desde a vida em oppidum ou urbs até, efetivamente, uma civitas -, ao constituir um populus e uma res publica, é expressa tecnicamente pelo particípio sociatus.

Uma questão que divide a bibliografia é a relação desta figura jurídica da societas utilizada por Cícero, em outros momentos do tratado, em paralelo ao particípio sociatus - na constituição da res publica. Alguns autores com diferentes teores tendem a interpretar assim a gênese da res publica ou do iuris consensus a partir da figura jurídica análoga ao contrato de societas do direito privado ${ }^{83}$. Tal interpretação, tomando a figura da societas do ius civile como paralelo, individualiza os principais elementos da societas consensu contracta e aplica-os na definição de Rep. 1.39: (1) a presença de uma affectio societatis plurilateral (aqui, para

${ }^{83}$ Não é o objetivo deste artigo aprofundar a comparação entre res publica e a societas privada. Um breve sumário sobre esta figura é relevante. No direito privado romano do período clássico (i.e., de finais da República até fim do Principado), como define Kaser, a societas é a "união [contratualconsensual] de duas ou mais pessoas para realizar um fim comum com meios comuns" (1999, p. 255). Sua raiz do direito antigo seria o consortium, forma jurídica ficta de manter juridicamente associados vários herdeiros (sui heredes) de um paterfamilias após a morte deste; o consortium já caíra em desuso nos tempos de Cícero, sobrevivendo na figura da societas omnium bonorum (quando todos os bens dos sócios, presentes e futuros, são alocados para a consecução da societas), que passa a se constituir no modelo da antiga consortium, sem as mesmas formalidades necessárias à formação daquela. A societas clássica se estabelece nudo consensu contrahitur (G. 3.154), isto é, pelo consensus livremente declarado dos socii (no que se distingue, portanto, dos contratos reais, re contrahi, como o contrato de mútuo ou depósito; e dos contratos uerba, como a antiga stipulatio). Não havia forma necessária para esse consenso: a cooperação factual basta para configurá-la. Ademais, um consensus permanente que liga todos os sócios originários: basta que um declare a vontade de separar-se que toda a societas clássicas se extinga, o que se chama affectio societatis (bem como os fatores comuns de extinção de obrigações: a morte de um dos sócios, a capitis deminutio ou a falência). A societas existe através de um patrimônio social (que, salvo convenção diversa, será formado por quotas iguais dos socii, em regime de copropriedade). Sendo um contrato consensual, entende-se que a societas é regida pela fides e, por isso, a societas era tutelada pela actio pro socio, uma bonae fidei iudicium, que teria por objeto a liquidação das contas e a compensação de dívidas e créditos recíprocos da relação de societas entre os socii. Ser um contrato consensual ex fide bona não significava, no entanto, que se pautava por uma noção de justiça distributiva "objetiva". A discussão era intensa ainda nos tempos de Cícero: Quinto Múcio Cévola desaprovava como contra naturam societatis a divisão não igualitária dos lucros, reivindicando a raiz do antigo consortum, que tornava iguais os herdeiros; Sérvio Sulpício Rufo, o jurisconsulto contemporâneo de Cícero, seu amigo e alvo no discurso pro Murena, defendia abertamente a possibilidade de que o consensus estabelecesse a quota-parte de perdas e lucros entre as partes; a ideia de justiça seria introduzida apenas por Sabino e Ulpiano nos tempos imperiais. A única proibição efetiva era a "sociedade leonina" (termo que não é jurídico, e sim, deriva de uma fábula, cf. Fedro, Fabulae Aesopiae, 1.5, "Vacca, capella, ovis, et leo"). Quanto às principais fontes cite-se: G., 3.89, G., 3.148154, G., 3.154a-b; Just. Inst. 3.25.2; Paul. D. 17.2.65; Ulp. D. 17.2.63pr.; Ulp. D. 17.2.29.2. Veja-se ainda Kaser, Max. Direito privado romano (Lisboa, Calouste Gulbenkian, 1999), p. 255-259; Zimmermann, Reinhard; The Law of Obligations: Roman Foundations of the Civilian Tradition (South Africa: Juta \& Co, 1990), p. 451-476; Alves, José Carlos Moreira Alves. Direito Romano (Rio de Janeiro, Forense, 2014), p. 531-535; Watson, Alan. "The Evolution of Law: The Roman System of Contracts" in: Law and History Review, vol. 2, n. 1, 1984, p. 15-16; Birks, Peter; Descheemaeker (editor). The Roman Law of Obligations: the collected papers of Peter Birks (Oxford: Oxford University Press, 2014), p. 110-118. 
Mancuso, ofertada pelo consensus iuris, vontade coletiva em forma técnica); (2) a par condicio dos sócios, neste caso, os cives; e (3) a presença de um escopo comum lícito e proveitoso a todos, que seria na res publica a utilitatis communio de Rep. 1.39. O vinculum societatis privado gera relações jurídicas obrigacionais entre os socii; se aplicado à res publica, o vinculum societatis seria, em última instância, o unum vinculum iuris. Para um dos estudiosos que advoga essa analogia, Lobrano, os romanos institucionalmente desdobraram e diferenciaram nos tempos de Cícero, por um lado, a maiestas do populus (a "soberania"), e o "governo", confiado aos magistrados, existindo entre ambos um elemento de garantia, a instituição do tribunato da plebe; tal conquistaria teria se dedo justamente pelo paradigma juspublicista da societas-res publica. Para Lobrano, esse paradigma demonstra uma "reciprocidade entre as instituições de direito privado e as instituições de direito público no interior de um sistema jurídico único". ${ }^{84}$

O principal fragmento do Digesto utilizado para tal analogia advém do comentário ao edito provincial de Gaio, cerca de dois séculos após os tempos de Cícero. Ao explicar o regime jurídico dos collegia (universitas) ${ }^{85}$ e das societates, Gaio adiciona a seguinte oração

${ }^{84}$ Lobrano, Giovanni. Res publica res populi: la legge e la limitazione del potere (Torino: G. Giapiccheli, 1996), p. 113-130; Lobrano, Giovanni. "A teoria da res publica (fundada sobre a 'sociedade' e não sobre a 'pessoa jurídica') no Corpus Juris Civilis de Justiniano (Digesto 1.2-4)" in Revista Sequência, n. 59, dez. 2009, p. 19-24. Lendo Cícero - especialmente Rep. 1.39, 1.41, Rep. 6.13 e De Off. 1.(societatis hominum), Lobrano enxerga a res publica (para ele, o populus é produto de um contrato de sociedade, populus-societas) como articulação central de uma "cadeia societária" que vai da família e da união conjugal até a humanidade. Há, de fato, como afirma Varvaro, uma perspectiva "contratualista". No entanto, é importante salientar que alguns trabalhos - mormente o do professor Lobrano - não se propõem apenas como trabalhos historiográficos sobre a República tardia ou comentários de autores como Cícero e Lívio, mas como pesquisas de direito romano público atual. Há o objetivo tanto de compreender historicamente um aspecto do direito romano como também seu devir ao longo dos séculos (razão para Lobrano se dedicar tanto às discrepâncias da teoria da res publica romana com Hobbes, Kant, Tocqueville e Sieyes, e aproximar este mesmo modelo daquele de Rousseau e Fichte). Como explica o próprio Lobrano, a exigência de estudar o direito público romano (mesmo que com um viés diferente dos predecessores da juspublicística do século XIX) é a de compreender influências recíprocas daquele com o atual direito público positivo, não para inventariar categorias e instituições ou propor combinações anacrônicas, mas perceber a complexidade dos mecanismos de escolhas politicas e mediações científicas ao longo do tempo (prestando atenção nas "seleções" e "falsificações" - ou poderíamos acrescentar, "interpretações" e novas "apropriações"). Lobrano, 1996, p. 50-54. Sendo assim, as opções e os objetivos de cada pesquisa precisam ser sopesados no momento da avaliação. Parece-nos diverso, por exemplo, de trabalhos como o de Wood ou Atkins, que efetivamente se propõem como análises de Cícero (e o contratualismo, ao invés de chave de leitura propositiva, é diretamente um erro, como na leitura "lockeana" que Atkins faz de Cícero).

${ }^{85}$ Associações (collegia, sodalitates, sodalicia), ainda que não no mesmo sentido técnico-jurídico que as modernas associações. A expressão universitas parece ser sinônima em muitos textos, mas implica mais exatamente uma das características destas associações: a existência de uma união, conjunto ou complexo (de coisas ou pessoas), seja uma herança (universitas bonorum), um municipium, collegium ou mesmo civitas. Os collegia sacerdotais constituem a forma mais antiga de collegium em Roma, seguidas de associações de ofícios e das societates publicanorum. As associações possuem suas próprias normas (lex collegii) e constituem um conjunto. Associações diferem-se da societas, uma vez que esta 
subordinada: "proprium est ad exemplum rei publicae habere res communes", reiterando "... tanquam in re publica". ${ }^{86}$ Gaio desejava demonstrar uma similitude entre estas três figuras: a res publica, como as demais figuras, corpus habet (D. 3.4.1pr.) e é sua característica possuir res communes (D. 3.4.1.1) ${ }^{87}$.

Não está em debate que tratado De Re Publica faça exsurgir um paralelo espontâneo com a figura da societas: o próprio Cícero falara abundantemente da societas privada em algumas de suas primeiras aparições públicas como patronus. ${ }^{88}$ A linguagem técnico-jurídica, bem como a linguagem religiosa e ritualística, é empregada por muitos autores da República num leque muito variado de ocasiões, justamente pela proximidade que os nobiles letrados tinham com o conhecimento do ius civile, do ius honorarium e do ius pontificium. ${ }^{89}$ A questão conceitual é se Cícero efetivamente pensa a res publica em um paralelo muito íntimo com a societas do ponto de vista estrutural, normativo, nos caracteres que o ius civile faria originar. ${ }^{90}$

é uma união contratual de várias pessoas e que produz obrigações apenas entre os sócios; como destaca Kaser, "para o exterior, a societas, ao contrário da associação, não se apresenta como unidade autónoma" (Kaser, 1999, p. 116).

${ }^{86}$ Gai. 3 ad ed. provinc., D. 3.4.1.1. "Quibus autem permissum est corpus habere collegii societatis sive cuiusque alterius eorum nomine, proprium est ad exemplum rei publicae habere res communes, arcam communem et actorem sive syndicum, per quem tamquam in re publica, quod communiter agi fierique oporteat, agatur fiat". Veja-se que esta è também implicitamente a interpretação de Vasconcellos ao traduzir: "É próprio daqueles a quem se permitiu estabelecer em tidades na forma de corporação, sociedade ou alguma outra como essas, ter, à semelhança do Estado, coisas em comum, uma caixa comum e um gestor ou síndico, por meio do qual - tal como ocorre com o Estado - seja demandado ou feito aquilo que a eles conjuntamente for necessário demandar ou fazer".

${ }^{87}$ Para as citações do Digesto de Justiniano, veja-se a recente edição: Vasconcellos, Manoel da Cunha Lopes. Digesto ou Pandectas do Imperador Justiniano. Trad. comp. e org. e de Eduardo C. Silveira Marchi, Bernardo B. Queiroz de Moraes e Dárcio R. Martins Rodrigues (São Paulo: YK Editora, 2017, 2 vols. até o presente).

${ }^{88}$ Especialmente nas orações Pro Roscio Comoedo (16, 22-32, 34-39, 51-55), de 76 a.C., ao defender o ator contra seu antigo sócio, e também na mais antiga oratio ciceroniana que se tem notícia, o pro Quinctio (3-6, 9, 13, 15, 16, 24), de 81 a.C. Pro Quinctio fora uma ação de direito penal, mas versou insistentemente sobre a societas relevante ao caso discutido; e Pro Roscio Amerino, embora ocorra em uma actio certae credtiae pecuniae movida contra o cliente de Cícero. Um de seus principais argumentos contra o pretenso débito de Róscio, para Cícero, dera-se justamente pela ampla contribuição de seu cliente para a societas, muito maior que a de seu ex-sócio. Ver Lintott, Andrew. Cicero as evidence: a historian's companion (New York; Oxford University Press, 2008), p. 43-67, para um tratamento em pormenor do uso de societas em ambas as orações.

${ }^{89}$ Para citar os exemplos óbvios de Lívio, Salústio e Varrão, o que permanece válido para autores do Principado como Gélio, Tácito e Plínio, o Jovem.

${ }^{90}$ Não é o lugar aqui para explorar a sofisticada questão da relação entre ius privatum e ius publicum (exemplos de definição encontram-se em Ulp. 30 ad. ed., D. 50.17.45.1, "privatorum conventio iuri publico non derogat"; e em Pap. 2 quaest. D. 2.14.38 "Ius publicum privatorum pactis mutari non potest"), e, independente desta divisão, dos seus conteúdos jurídicos dentro do ius civile (D. 2.1.1.7). A divisão conceitual existe nos próprios romanos, mas ainda é uma controvérsia a relação entre essas esferas, especialmente, do estatuto epistemológico ou científico do ius publicum quando comparado ao 
Existem limites bastante fortes, contudo para uma transposição dos dois institutos. A societas contratual do direito privado não forma uma entidade jurídica autônoma erga omnes, e sim, cria relações entre os seus socii (e somente entre eles). Como anotou Varvaro a este respeito $^{91}$ é difícil transpor para uma sociedade privada, que se solidifica pelo consensus de alguns indivíduos privados entre si, a complexidade e a universalidade que a res publica parece invocar. Orestano, neste tópico, invoca o argumento varroniano que distingue o populus (in sua potestate) dos singuli ${ }^{92}$, dos cives tomados individualmente. Tal fica evidente na possibilidade de dissolução a qualquer tempo de uma societas contratual por conta da morte ou da mudança de status de um dos sócios enquanto a res publica - que é res populi - não se dissolve ainda que se altere constantemente a composição de seus indivíduos. ${ }^{93}$

Lembre-se também, com Orestano, que é preciso levar em conta que os compiladores do Digesto (já no século VI d.C.), ao selecionar o fragmento de Gaio (D. 3.4.1.1), estavam engajados em compor uma exposição geral e unitária ao agregar várias figuras pessoais próximas. ${ }^{94}$ Frente ao texto de um jurisconsulto clássico como Gaio, o fragmento foi recortado pelos compiladores justamente por oferecer, no animus da compilação justinianeia - não

direito privado na formação da iuris civilis scientia clássica. É certo que o direito privado recebeu grande atenção na compilação justinianeia (seguindo, ademais, os modelos do edictum perpetuum, seguido pelos iuris civili libri e commentarii dos juristas) e é difícil distinguir porções específicas "de direito público". Isso se dá mais pelo caráter da compilação de Justiniano, no entanto, do que por uma inexistência de tratamento do direito público, seja entre os jurisconsultos romanos clássicos (pensamos na longa bibliografia de Ulpiano e Paulo sobre tópicos juspublicísticos), seja entre as normas jurídicas (pensemos nos Codices de Teodósio e Justiniano, ou na lex de imperio Vespasiani). É certo que dois são os riscos que, como apontou Lobrano, precisam ser evitados: por um lado, "estatalizar" o direito público romano, no afã de compreender sua técnica e dogmática (tornando-o uma "ciência jurídica do Estado" aos moldes de um Jellinek) e, por outro, ao negar-lhe qualquer profundidade dogmática, privá-lo de qualquer tessitura jurídica. Vide Lobrano, 1996, p. 45.

${ }^{91}$ Varvaro, 1998, p. 453-457.

92 Varr. De ling. lat. 9.6: "Populus enim in sua potestate, singuli in illius: itaque ut suam quisque consuetudinem, si mala est, corrigere debet, sic populus suam. Ego populi consuetudinis non sum ut dominus, at ille meae est. Ut rationi optemperare debet gubernator, gubernatori unus quisque in navi, sic populus rationi, nos singuli populo. Quare ad quamcumque summam in dicendo referam si animadvertes, intelleges, utrum dicatur analogia esse an uti oportere ea; itemque intelleges si ad analogiam usum loquendi oporteat redigere, tum dici id in populum aliter ac in singulos nec idem de omnibus dici in eum qui sit in populo". Como acrescenta Orestano, "Questa espressione [= populus ... in sua potestate], in cui è indubbio il riferimento a precisi concetti giuridici, sintetizza secoli di esperienza repubblicana: il populus come colletività trascende i singuli; ma i singuli in quanto populus como i 'signori' di se stessi, in sua potestate", vide Orestano, 1968, p. 217.

${ }^{93}$ Alf. 6 dig. D. 5.1.76, lembra-nos Varvaro, oferece-nos um responsum de Sérvio Sulpício Rufo a esse propósito: "et populum eundem hoc tempore putari qui abhinc centum annis fuissent, cum ex illis nemo nunc viveret".

${ }^{94}$ Orestano,1968, p. 170-178. 
necessariamente, do direito clássico -, a possibilidade de elaboração mais sistemática de uma dada categoria jurídica (universitates), particularmente importante no contexto histórico bizantino e cristão. E independentemente do grau de interpolação que se possa assinalar para o texto de Gaio, é certo que ele não é uma conceituação de res publica nem, ademais, estava contido num livro de direito público, mas num comentário ao edito provincial.

Acrescentemos a isso que a expressão societas - e termos correlatos - tem vida própria para além da societas privada nos contextos filosófico, retórico e historiográfico. Pensar no socius utilizado no ius gentium para outros povos que possuem tratado de aliança (foedus). Cícero está ciente do que os iurisprudentes tinham a dizer a respeito da societas, e nem por isso deixa de empregar o termo para se expressar a laços naturais (De Off. 1.54), laços de amicitia (De Off. 1.55-56), cidadania (De Off. 1.57), os laços universais da humanidade (De Off. 1.53; 3.28). Fora dos tratados filosóficos, o termo socius - remetendo à sua origem no ius fetiale e no ius gentium como aquele que designa um povo que possui aliança, foedus, com Roma - é empregado diversas vezes: socius pode ser sinônimo de amigo ou companheiro, como Ático (Att. 1.18) e Públio Lêntulo (Dom. 12), ou como um indivíduo aliado de Roma (Rep. 2.14; Sest. 26; Verr. 2.3.57). Também nesse prisma a societas é invocada quando Cícero quer indicar uma relação de confiança e honestidade, seja com um indivíduo (v.g. Phil. 7.2, ao referir-se a Gaio Pansa), seja com outro povo aliado (Dom. 8). Em todos estes casos há uma matriz comum na qual societas e socius indicam associação, proximidade e aliança; diferentes esferas da vida humana, no entanto - seja a institucional pública ou privada, seja o âmbito das relações entre os povos, seja o âmbito da moral privada - preenchem esse termo com seus próprios conteúdos. Cícero escolhe o termo por essas razões, mas nem por isso ele extrai o tipo de associação que forma a res publica, o populus, da societas privada. A escolha também pode ter se dado primordialmente por oferecer uma contraposição ao vocábulo congregatus e firmar, na leitura ciceroniana da origem da sociedade, a distinção qualitativa entre a vida coletiva primitiva e a efetiva comunidade política.

Parece-nos que é melhor tomar à societas-sociatus em Rep. 1.39 (em confronto com o texto de Gaio no Digesto) seguramente como evidência de duas coisas, aquelas que o fragmento realmente pode assegurar. A primeira, a existência efetiva tanto das normas quanto uma reflexão teórica a respeito desse complexo normativo que regula a res publica (seja em Cícero, seja em Gaio, a res publica é percebida como uma entidade de existência jurídica, não apenas uma questão de fato). A segunda, que o intercâmbio entre societas e res publica (e collegia) que faz Gaio através da expressão ad exemplum não indica uma relação de subordinação (nem, ousamos dizer, necessariamente de "reciprocidade", ao menos não no sentido de equivalência) 
entre direito público e direito privado. O direito público romano não é simplesmente o gêmeo mais novo do direito privado (como advogava as mais datadas considerações a respeito de sua "inexistência" no mundo romano), tampouco um ponto antipodal ou um reflexo no espelho. Palavras comuns podem dar ensejo a conceitos que se sofisticam e se aperfeiçoam e, no mais das vezes, a conceitos homônimos que não são sinônimos.

\section{Conclusões finais}

O tratado De Re Publica é tanto uma peça de diálogo filosófico quanto testemunho da cultura política e jus-institucional de um nobilis dentro dos conturbados anos da República tardia que antecedem o assassinato de César e os rearranjos constitucionais do Principado de Augusto. É simultaneamente uma obra profundamente ligada à forma como um homem particular enxergava o estado de coisas que cercava a res publica e como podia empregar sua doctrina e sua auctoritas. Sem dúvida, retomando a consideração de Wiseman mencionada na primeira nota deste artigo, não se tratava de uma análise desapaixonada e nem se propunha como tal. O conjunto de escritos filosóficos de Cícero dos anos cinquenta (De Oratore, De Re Publica, De Legibus) foi concebido de modo perfeitamente pragmático, uma adequada intromissão da erudição dos docti nos negotia dos cidadãos e dos homens públicos. Ao longo da primeira parte deste artigo buscamos enfatizar esse localizado (e nenhum problema ser ele, também, autointeressado) aspecto contextual na confecção de seu De Re Publica.

Tivemos em conta não apenas o elemento moral ou o elemento jusnaturalista que eiva os tratados De Re Publica e de Legibus, mas também o seu aspecto institucional, necessário para integralizar sua leitura. É diante destas balizas que buscamos subsídios para interpretar, ao longo de nossa segunda seção, a definição de res publica como res populi (Rep. 1.39). Levamos em conta a reciprocidade dos dois elementos constituintes do populus, o iuris consensus e a utilitatis communio, e que aquele é resultado de uma união muito qualificada de homens (sociatus), sofisticando uma tendência gregária já intrínseca. O momento fundacional em Cícero não é um contrato no sentido da filosofia moderna, mas enfatiza o papel da criação coletiva do complexo normativo que regerá uma civitas. Os cidadãos possuem participação dúplice no direito, tanto aquele que comungam naturalmente quanto aquele que é criação peculiar dos tempos e das específicas civitates.

O objetivo último de Cícero, uma vez que Roma já se encontrava fundada e funcional, era a sua conservação (Rep. 1.12). É a isto que se reportam em última instância todas as discussões sobre de optimo statu civitatis e de optimo cive (ad Q. F. 3.5.1), flanqueadas 
permanentemente pela realidade do direito, das instituições e dos costumes dos romanos. A história e o funcionamento das instituições de Roma precisam ser conhecidos por aqueles que treinados por uma educação moral e intelectual exigente (Rep. 5.1, 5.5) manteriam constantemente o funcionamento aequibiliter da res publica.

\section{Referências bibliográficas}

Alves, José Carlos Moreira Alves. Direito Romano (Rio de Janeiro, Forense, 2014).

Ando, Clifford. Roman social imaginaries: language and thought in contexts of Empire (Buffalo: University of Toronto Press, 2015).

Anselmo, Giuseppina Aricò. "Ius publicum-ius privatum in Ulpiano, Gaio e Cicerone" in AUPA [Annali del Seminario Giuridico della Università di Palermo], vol. 37, 1983, p. 445-773. Disponível em: < http://www1.unipa.it/ dipstdir/pub/annali/Annali\%201983/Annali\%2037\%201983.pdf >. Acesso: 12 abr. 2018.

Aristotle. Política, trad. Manuela García Valdés (Madrid: Gredos, 1988).

Aristotle. Nicomachean Ethic, translated by W. D. Ross (Princeton: Princeton University Press, 1995).

Asmis, Elizabeth. "The State as a Partnership: Cicero's Definition of Res Publica in his work On The State" in: History of Political Thought, vol. 25, 2004, p. 569-598. Disponível em: < http://www.jstor.org/stable/26220253 >. Acesso: 12 abr. 2018.

Atkins, Jed. W. Cicero on Politics and the Limits of Reason: The Republic and The Laws (Cambridge: Cambridge University Press, 2013).

Augustine. City of God, 6 vol., translated by David S. Wiesen (New York: Harvard University Press, 1957-1968).

Bernardo, Isadora Prévide. O De Re Publica, de Cícero: natureza, política e história. 2012. Dissertação (Mestrado em Filosofia) - Faculdade de Filosofia, Letras e Ciências Humanas, Universidade de São Paulo, São Paulo, 215 p. Disponível em: < http://www.teses.usp.br/teses/disponiveis/8/8133/tde25042013-120804/publico/2012_IsadoraPrevideBernardo_VCorr.pdf >. Acesso: 12 abr. 2018.

Birks, Peter; Descheemaeker (editor). The Roman Law of Obligations: the collected papers of Peter Birks (Oxford: Oxford University Press, 2014).

Brooks, Richard O. (ed). Cicero and Modern Law (Burlington: Ashgate, 2009).

Butler, Shane. "Cicero's capita" in Jansen, Laura (ed.). The Roman Paratext: frame, texts, readers (New York: Cambridge University Press, 2014), p. 73-111.

Cascione, Cosimo. Consensus: problemi di origine, tutela processuale, prospettive sistematiche (Napoli: Editoriale Scientifica, 2003).

Cancelli, Filippo. "'Iuris consensu' nella definizione ciceroniana di 'Respublica'" in Rivista di Cultura Classica e Medioevale, vol. 4, 1972, p. 247-267. 
Clark, Gillian; Rajak, Tessa (eds.). Philosophy and Power In the Graeco-Roman World: Essays in Honour of Miriam Griffin (Oxford: Oxford University Press, 2002).

Cicero, Marcus Tullius. M. Tulli Ciceronis De Re Publica quae supersunt, ed. Angelo Mai (Roma: Collegio Urbano apud Burliaeum, 1822), Disponível em: < https://babel.hathitrust.org/cgi/ pt?id=nyp. $33433081620779>$.

Cicero, Marcus Tullius. De Re Publica, librorum sex quae man serunt, ed. Konrat Ziegler. (Leipzig: Teubner, 1915).

Cicero, Marcus Tullius. Pro Lege Manilia. Pro Caecina. Pro Cluentio. Pro Rabirio Perduellionis Reo, translated by H. Grose Hodge (New York: Harvard University Press, 1927).

Cicero, Marcus Tullius. On the nature of Gods. Academics, translated by H. Rackham (New York: Harvard University Press, 1933).

Cicero, Marcus Tullius. On invention. Best kind of orator. Topics, translated by H. M. Hubbel (New York: Harvard University Press, 1949).

Cicero, Marcus Tullius. Brutus. Orator, translated by G. L. Hendrickson, H. M. Hubbell (New York: Harvard University Press, 1962).

Cicero, Marcus Tullius. On the Commonwealth and On the Laws, translated by James E. G. Zetzel (Cambridge: Cambridge University Press, 1999).

Cicero, Marcus Tullius. Letters to Atticus, 4 vol., translated by D. R. Shackleton Bailey (Harvard: Harvard University Press, 1999).

Cicero, Marcus Tullius. Dos Deveres: De Officiis, trad. Carlos Humberto Gomes (Lisboa: Edições 70, 2000).

Cicero, Marcus Tullius. Letters to Friends, 3 vol., translated by D. R. Shackleton Bailey (Harvard: Harvard University Press, 2001).

Cicero, Marcus Tullius. Letters to Quintus and Brutus, translated by D. R. Shackleton Bailey (Harvard: Harvard University Press, 2002).

Cicero, Marcus Tullius. Do sumo bem e do sumo mal, trad. Carlos Ancêde Nougé (São Paulo: Martins Fontes, 2005).

Cicero, Marcus Tullius. Tratado da República, trad. Francisco de Oliveira (Lisboa: Círculo de Leitores, 2008).

Cicero, Marcus Tullius. De Oratore, trad. Adriano Scatolin, in Scatolin, Adriano. A invenção no Do Orador de Cícero: um estudo à luz de Ad Familiares I, 9, 23 (Tese de Doutorado - Letras Clássicas Faculdade de Filosofia, Letras e Ciências Humanas, Departamento de Letras Clássicas e Vernáculas, 2009.

Corral, Ildefonso L. García del. Cuerpo del derecho civil romano, 6 vol. (Barcelona: Lex Nova, 2004).

Correia, Alexandre; Correia, Alexandre A. de Castro; Sciascia, Gaetano. Manual de Direito Romano: Institutas de Gaio e de Justiniano vertidas para o português, em confronto com o texto latino, vol. 2. (São Paulo, Saraiva, 1955).

Cornell, T. J. "Cicero on the Origins of Rome" in Powell, Jonathan G. F.; North, J. A. Cicero's Republic: Bulletin of the Institute of Classical Studies, Supplement n. 76, 2001, p. 41-56.

Dyck, Andrew Roy. A Commentary on Cicero, De Legibus (Ann Arbor: University of Michigan Press, 2004).

Faria, Ernesto. Gramática Superior da Língua Latina (Rio de Janeiro: Livraria Acadêmica, 1958).

Finley, Moses I. Politics in the Ancient World (Cambridge: Cambridge University Press, 1983). 
Forschner, Benedikt. "Law's Nature: Philosophy as a Legal Argument in Cicero's Writings" in Du Plessis, Paul J. (ed.). Cicero's Law: Rethinking Roman Law of the Late Republic (Edinburgh: Edinburgh University Press, 2017), p. 50-67.

Frier, Bruce W. The rise of the Roman Jurists: Studies in Cicero's "Pro Caecina" (Princeton, New Jersey: Princeton University Press, 1985).

Glucker, John. "Carneades in Rome - some Unsolved Problems" in Powell, Jonathan G. F.; North, J. A. Cicero's Republic: Bulletin of the Institute of Classical Studies, Supplement n. 76, 2001, p. 57-82.

Hammer, Dean. Roman political thought: from Cicero to Augustine (New York: Cambridge University Press, 2014).

Harries, Jill Diana. Cicero and the Jurists: From Citizens' Law to the Lawful State (London: Duckworth, 2006).

Harries, Jill Diana. "Cicero and the Definition of the Ius Civile" in Clark, Gillian; Rajak, Tessa (eds.). Philosophy and Power In the Graeco-Roman World: Essays in Honour of Miriam Griffin (Oxford: Oxford University Press, 2002), p. 51-68.

Hellegouarc'h, Joseph. Le Vocabulaire Latin des relations et des partis politiques sous la République (Paris: Les Belles Lettres, 1963).

Horrocks, Geoffrey. "Latin Syntax" in Clackson, James (editor). A Companion to Latin Language (Hoboken: Wiley-Blackwell, 2011), p. 118-142.

Jones, Peter V.; Sidwell, Keith. Aprendendo latim (São Paulo: Odysseus, 2012).

Lactantius, Lucius Caecilius Firmianus. Divine institutes, translated by Anthony Bowen, Peter Garnsey (Liverpool: Liverpool University Press, 2003).

Lima, Sidney Calheiros de. Aspectos do gênero dialógico no De Finibus de Cícero. 2009. Tese (Doutorado em Linguística, Área de Letras Clássicas) - Instituto de Estudos da Linguagem, Universidade Estadual de Campinas, Campinas, 652 p. Disponível em: $<$ http://repositorio.unicamp.br/ bitstream/REPOSIP/271116/1/Lima_SidneyCalheirosde_D.pdf >. Acesso: 12 abr. 2018.

Lima, Sidney Calheiros de. "Cícero e a obra filosófica em latim como munus rei publicae" in Nuntius Antiquus, n. 5, 2010, p. 92-110. DOI: < http://dx.doi.org/10.17851/1983-3636.5.0.92-110 >. Acesso: 12 abr. 2018.

Lintott, Andrew. The Constitution of the Roman Republic (Oxford: Oxford University Press, 1999).

Lintott, Andrew. Cicero as evidence: a historian's companion (New York; Oxford University Press, 2008).

Lobrano, Giovanni. Res publica res populi: la legge e la limitazione del potere (Torino: G. Giapiccheli, 1996).

Lobrano, Giovanni. “A teoria da res publica (fundada sobre a 'sociedade' e não sobre a 'pessoa jurídica') no Corpus Juris Civilis de Justiniano (Digesto 1.2-4)" in Revista Sequência, n. 59, dez. 2009, p. 13-41. DOI: < http://dx.doi.org/10.5007/2177-7055.2009v30n59p13 >. Acesso: 12 abr. 2018.

Kaser, Max. Direito privado romano (Lisboa, Calouste Gulbenkian, 1999).

Kempshall, M. S.. "De Re Publica 1.39 in Medieval and Renaissance Political Thought" in Powell, Jonathan G. F.; North, J. A. Cicero's Republic: Bulletin of the Institute of Classical Studies, Supplement n. 76, 2001, p. 41-56.

Kohns, Hans Peter. "Consensus iuris - communio utilitatis (zu Cic. Rep. I 39)" in Gymnasium Heidelberg, vol 81, 1974, p. 485-498.

Mai, Angelo. M. Tulli Ciceronis De Re Publica quae supersunt (Roma: Collegio Urbano apud Burliaeum, 1822). Disponível em: < https://babel.hathitrust.org/cgi/pt?id=nyp.33433081620779 >. Acesso: 12 abr. 2018. 
Mancuso, Gaetano. "Potere e consenso nell'esperienza costituzionale romana" in AUPA [Annali del Seminario Giuridico della Università di Palermo], vol. 41, 1991, p. 209-222. Disponível em: < http://www1.unipa.it/ dipstdir/pub/annali/Annali\%201991/Annali\%2041\%201991.pdf >. Acesso: 12 abr. 2018.

Marx, Karl. "Notebooks on Epicurean Philosophy" [1839] in Marx, Karl; Engels, Friedrich. Marx \& Engels Collected Works: Vol. 1, Karl Marx, 1835-43. (Lawrence \& Wishart/Eletric Book, 2010), p. 403 509 .

Mommsen, Theodor. Römische Geschichte: Bd. von Sullas Tode bis zur Schlaft von Thapsus (Berlin: Weidmannsche Buchhandlung, 1856, vol. 3-3). Disponível em $<$ https://archive.org/details/ bub_gb_3ok8AAAAIAAJ >.

Oliveira, Francisco de. Tratado da República: Cícero (tradução do latim, introdução e notas) (Lisboa: Circulo de Leitores \& Temas e Debates, 2008).

Orestano, Riccardo. Il problema delle persone giuridiche' in diritto romano (Torino: G. Giappichelli, 1968).

Plato. Gorgias and Phaedrus, translated by James H. Nichols Jr. (London: Cornell University Press, 1998).

Powell, Jonathan G. F. (editor). Cicero the philosopher: twelve papers (Oxford: Clarendon Press, 1995).

Powell, Jonathan G. F.; North, J. A. Cicero's Republic: Bulletin of the Institute of Classical Studies, Supplement n. 76, 2001, Disponível em: < https://doi.org/10.1111/j.2041-5370.2001.tb02125.x >. Acesso: 12 abr. 2018.

Powell, Jonathan G. F. "Were Cicero's Laws the Laws of Cicero's Republic?" in Powell, Jonathan G. F.; North, J. A. Cicero's Republic: Bulletin of the Institute of Classical Studies, Supplement n. 76, 2001, p. 17-39.

Powell, Jonathan G. F. M. Tulli Ciceronis De Re Publica, De Legibus, Cato Maiore de Senectute, Laelius de Amicitia (Oxford: Oxford University Press, 2006).

Schmidt, P. L. "The original version of the De Re Publica and the De Legibus" in Powell, Jonathan G. F.; North, J. A. Cicero's Republic: Bulletin of the Institute of Classical Studies, Supplement n. 76, 2001 p. 7-16.

Schofield, Malcolm. "Cicero's definition of res publica" in Powell, Jonathan G. F. (editor). Cicero the philosopher: twelve papers (Oxford: Clarendon Press, 1995), p. 63-83.

Schofield, Malcolm. "Writing philosophy" in Steel, Catherine (editor). The Cambridge Companion to Cicero (Cambridge: Cambridge University Press, 2013), p. 73-87.

Silva filho, Luiz Marcos da. "A conjunção et na definição ciceroniana de populus" in Cadernos de Filosofia Alemã, n. 21, 2013, p. 85-96. DOI: < http://dx.doi.org/10.11606/issn.2318-9800.v0i21p85-96 >. Acesso: 12 abr. 2018.

Syme, Ronald. The Roman Revolution (Oxford: Clarendon University Press, 1939).

Sprute, Jürgen. "Rechts- und Staatsphilosophie bei Cicero" in Phronesis, vol. 28, n. 2, 1983, p. 150-176. DOI: $<10.1163 / 156852883$ X00095 >. Acesso: 12 abr. 2018.

Varvaro, Mario. "Iuris consensus e societas in Cicerone: un'analisi di Cic., de rep., I, 25, 39" in AUPA [Annali del Seminario Giuridico della Università di Palermo], vol. 54, n. 1, 1998, p. 445-481.

Vasconcellos, Manoel da Cunha Lopes. Digesto ou Pandectas do Imperador Justiniano Trad. comp. e org. e de Eduardo C. Silveira Marchi, Bernardo B. Queiroz de Moraes e Dárcio R. Martins Rodrigues (São Paulo: YK Editora, 2017, 2 vols.).

Watson, Alan. "The Evolution of Law: The Roman System of Contracts" in Law and History Review, vol. 2, n. 1, 1984, p. 1-20. Disponível em: < http://digitalcommons.law.uga.edu/cgi/viewcontent.cgi? article $=1491 \&$ context $=$ fac_artchop $>$. Acesso: $24 / 01 / 2018$. 
Wiseman, Timothy Peter. "Roman History and Ideological Vacuum" in Remembering the Roman People: essays on Late-Republican Politics and Literature (Oxford: Oxford University Press, 2009).

Wood, Neal. Cicero's Social \& Political Thought (Berkeley: University of California Press, 1988).

Zetzel, James E. G. "Cicero and the Scipionic Circle" in Harvard Studies in Classical Philology, vol. 76, 1972, p. 173-179. DOI: < 10.2307/310983 >. Acesso: 12 abr. 2018.

Zetzel, James E. G. "Natural Law and Poetic Justice: a Carnedean in Cicero and Virgil" in Classical Philology, vol. 91, n. 4, 1996, p. 297-319. Disponível em: < http://www.jstor.org/stable/270437>. Acesso: 12 abr. 2018.

Zetzel, James E. G. "Political Philosophy" in Steel, Catherine (editor). The Cambridge Companion to Cicero (Cambridge: Cambridge University Press, 2013), p. 181-195.

Ziegler, Konrat. Marcus Tullius Cicero: De re publica, librorum sex quae man serunt (Lepzig: Teubner, 1915).

Ziegler, Konrat. "Zu Text und Textgeschichte der Republik Ciceros" in Hermes, vol. 66. Bd., H. 4, 1931, p. 268-301. Disponível em: < https://www.jstor.org/stable/4474218 >. Acesso: 12 abr. 2018.

Zimmermann, Reinhard; The Law of Obligations: Roman Foundations of the Civilian Tradition (South Africa: Juta \& Co, 1990). 